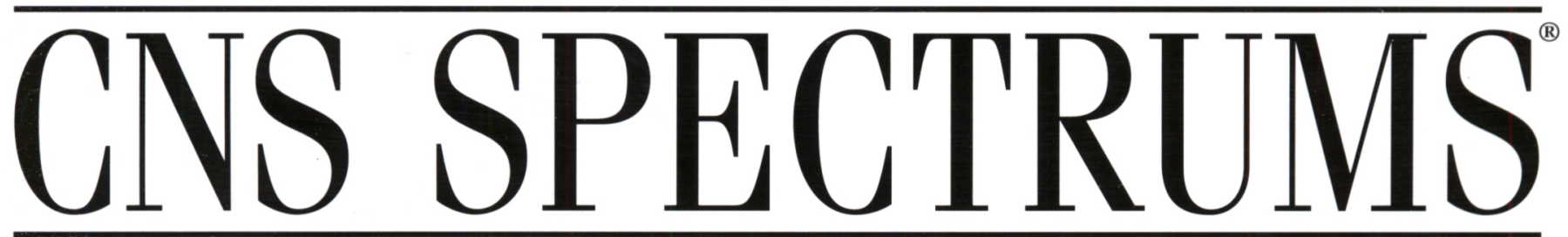

The International Journal of Neuropsychiatric Medicine

\title{
9
}

\section{Epilepsy: Diagnosis and Treatment in the 21st Century}

Seizure Types, Epilepsy Syndromes, Etiology, and Diagnosis

\author{
J.C. Edrwards
}

Antiepileptic Drugs in the 21st Century

C.W. Bazil

ORIGINAL RESEARCH

Vagus Nerve Stimulation and Lennox-Gastaut Syndrome:

A Review of the Literature and Data From the VNS Patient Registry

S. Karceski

ORIGINAL RESEARCH

Reproductive Dysfunction in Women

With Epilepsy: Antiepileptic Drug Effects

on Sex-Steroid Hormones

M.J. Morrell, K.L. Flynn, C.G. Seale, et al

ORIGINAL RESEARCH

Cognitive Difficulties and

Posttraumatic Stress Disorder in

Female Victims of Intimate Partner Violence

C.M. Kennedy, L. Tarokh, and M.B. Stein 


\section{In mild to moderate Alzheimer's disease}

\section{You see it as maintaining cognitive}

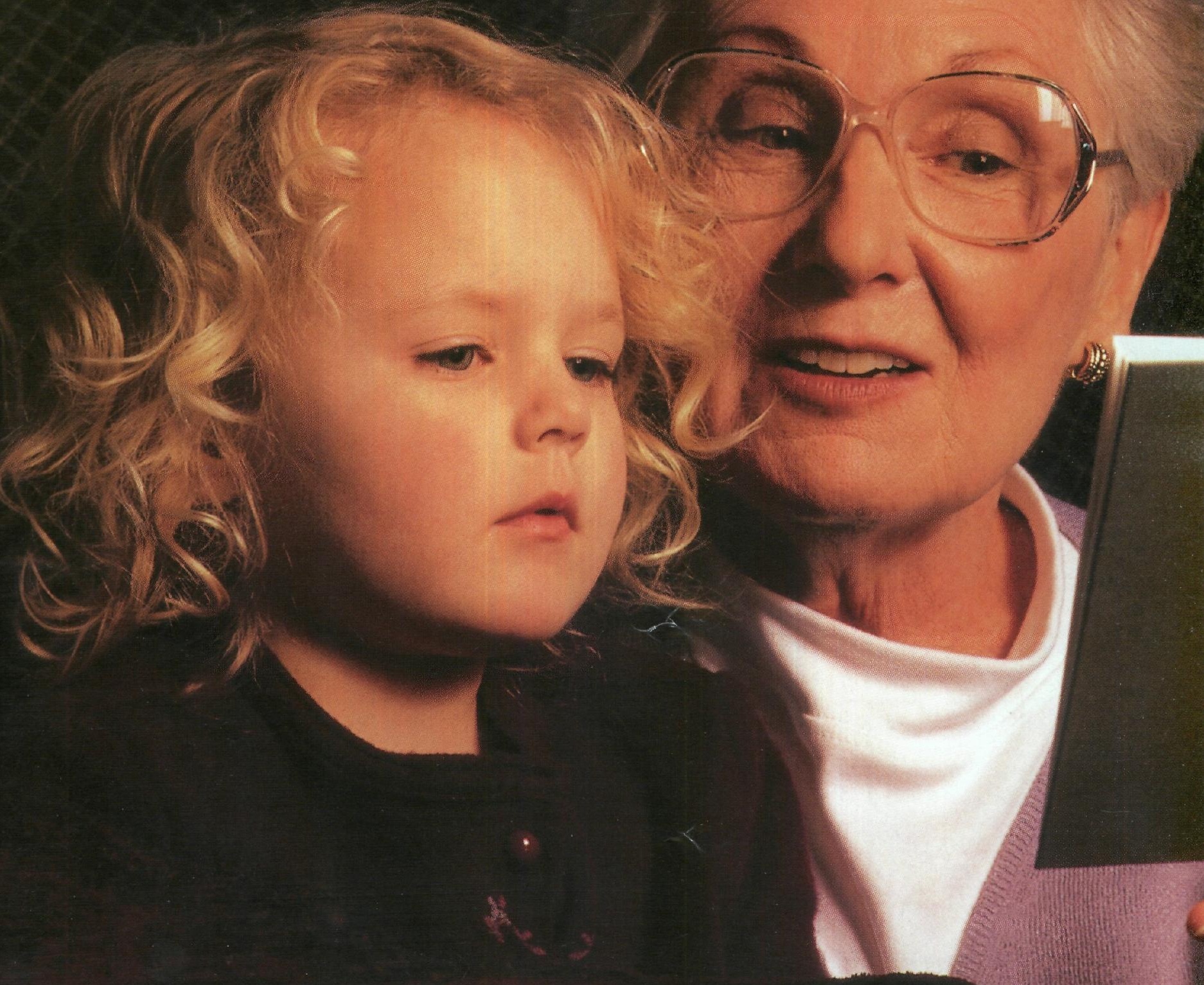

* Individual responses to ARICEPT ${ }^{\oplus}$ may include improvement, stabilization, or decline.

$\dagger$ The most common adverse events in pivotal clinical trials with ARICEPT $^{\circledR}$ were nausea, diarrhea, insomnia, vomiting, muscle cramps, fatigue, and anorexia. Pivotal clinical trials of ARICEPT $^{\circledR}$ have shown no increase, relative to placebo, in the incidence of either peptic ulcer disease or gastrointestinal bleeding. Nevertheless, cholinesterase inhibitors may be expected to increase gastric acid secretion. Therefore, patients (especially those at increased risk for developing ulcers-eg, having a history of ulcer disease, receiving concurrent nonsteroidal anti-inflammatory drugs) should be monitored closely for gastrointestinal bleeding. In pivotal clinical trials, syncopal episodes have been reported in association with ARICEPT $^{\circledR}$ ( $2 \%$ vs $1 \%$ for placebo). 


\section{function.}

\section{She sees it as a bedtime story.}

- Slows the worsening of symptoms*

- Proven to maintain cognition in placebo-controlled studies

- Well tolerated ${ }^{\dagger}$

- Proven safety profile

- Once-daily dosing

- 3 years of real-world use

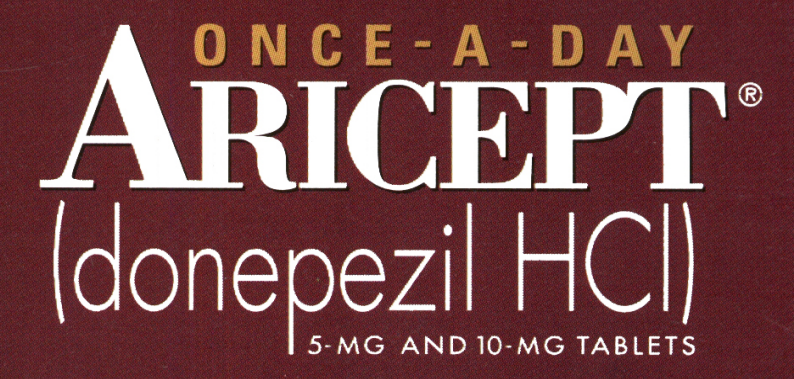

Therapy to REMEMBER"

Please see brief summary of prescribing information on adjacent page. 


\section{0-Day Planner}

\section{October}

\begin{tabular}{|c|c|c|c|c|c|c|}
\hline Sunday & Monday & Tuesday & Wednesday & Thursday & Friday & Saturday \\
\hline & 1 & 2 & 3 & $4(-6)$ & $5(-7)$ & 6 \\
\hline & & & & $\begin{array}{l}\text { International Society } \\
\text { for the Study of } \\
\text { Personality Disorders: } \\
\text { 7th International } \\
\text { Congress, } \\
\text { New York, NY } \\
\text { contact: } \\
\text { Tel: 212-305-3334 } \\
\text { Fax: 212-781-6047 }\end{array}$ & $\begin{array}{l}\text { 2nd Congress of } \\
\text { the Hellenic } \\
\text { Stroke Society: } \\
\text { Athens, Greece } \\
\text { contact: } \\
\text { Tel: } 30-31-260-645 \\
\text { Fax: } 30-31-260-645 \\
\text { nicart@med.auth.gr }\end{array}$ & \\
\hline \multirow[t]{2}{*}{7} & 8 & 9 & $10(-13)$ & $11(-13)$ & 12 & $13(-17)$ \\
\hline & \multicolumn{2}{|l|}{ Columbus Day — USA } & $\begin{array}{l}\text { Mental and Behavioral } \\
\text { Dysfunction in } \\
\text { Movement Disorders: } \\
\text { Montreal, Canada } \\
\text { contact: } \\
\text { Tel: 514-848-1133 } \\
\text { Fax: 514-288-6469 } \\
\text { bedard.marc-andre@ } \\
\text { uquam.ca }\end{array}$ & $\begin{array}{l}\text { 1st Canadian } \\
\text { Colloquium } \\
\text { on Dementia: } \\
\text { Toronto, Canada } \\
\text { contact: } \\
\text { Tel: } 416-340-5304 \\
\text { Fax: 416-340-4198 } \\
\text { rkeren@home.com }\end{array}$ & $\begin{array}{l}\text { Johns Hopkins: } \\
\text { Neuroradiology } \\
\text { Review With } \\
\text { Case Reviews, } \\
\text { Baltimore, MD } \\
\text { contact: } \\
\text { Tel: 410-955-2959 } \\
\text { Fax: 410-955-0807 } \\
\text { cmenet@jhmi.edu }\end{array}$ & $\begin{array}{l}\text { European College of } \\
\text { Neuropsycho- } \\
\text { pharmacology: } \\
\text { 14th Congress, } \\
\text { Istanbul, Turkey } \\
\text { contact: } \\
\text { Tel: } 31-30-253-8567 \\
\text { Fax: } 31-30-253-8568\end{array}$ \\
\hline \multirow[t]{2}{*}{14} & \multirow[t]{2}{*}{15} & \multirow[t]{2}{*}{16} & 17 & \multirow[t]{2}{*}{18} & \multirow[t]{2}{*}{19} & \multirow[t]{2}{*}{20} \\
\hline & & & $\begin{array}{l}\text { The Royal College } \\
\text { of Pathologists: } \\
\text { What's New } \\
\text { in Pediatric } \\
\text { Neuropathology, } \\
\text { London, UK } \\
\text { contact: } \\
\text { Tel: 2-74-516-700 } \\
\text { Fax: 2-74-516-701 } \\
\text { info@rcpath.org }\end{array}$ & & & \\
\hline $21(-26)$ & 22 & 23 & 24 & $25(-27)$ & 26 & 27 \\
\hline \multicolumn{2}{|l|}{$\begin{array}{l}\text { World Conference } \\
\text { Sleep 0dyssey 2001: } \\
\text { Punta del Este, Uruguay } \\
\text { contact: } \\
\text { Tel: 59-80-92-43-414 } \\
\text { x3409 } \\
\text { Fax: 59-82-92-48-784 } \\
\text { sleep2001@ } \\
\text { fmed.edu.uy }\end{array}$} & & & \multicolumn{2}{|l|}{$\begin{array}{l}\text { Neuromuscular } \\
\text { Disorders in } \\
\text { Pediatrics: } \\
\text { St. Louis, M0 } \\
\text { contact: } \\
\text { Tel: 800-553-2712 } \\
\text { Fax: 314-776-4395 } \\
\text { cme@slu.edu }\end{array}$} & $\begin{array}{l}\text { New York University } \\
\text { School of:Medicine: } \\
\text { Review of Practice } \\
\text { Guidelines for } \\
\text { Treatment of } \\
\text { Psychiatric Disorders, } \\
\text { New York, NY } \\
\text { contact: } \\
\text { wnw.med.nyu.edu/ } \\
\text { cme/ }\end{array}$ \\
\hline \multirow[t]{2}{*}{28} & \multirow[t]{2}{*}{29} & \multirow[t]{2}{*}{30} & 31 & & & \\
\hline & & & $\begin{array}{l}\text { November CNS } \\
\text { closes \& ships } \\
\text { to printer }\end{array}$ & $\begin{array}{l}\text { 37th Annual Turkish } \\
\text { Neurological Congress: } \\
\text { Antalya, Turkey } \\
\text { (0ct 31-Nov 4) } \\
\text { contact: } \\
\text { Tel: 90-46-23-258-309 } \\
\text { Fax: 90-46-23-269-192 } \\
\text { mozmenoglu@usa.net }\end{array}$ & $\begin{array}{l}\text { Harry Benjamin } \\
\text { : International Gender } \\
\text { Dysphoria Association } \\
\text { 17th Symposium, } \\
\text { Galveston, TX } \\
\text { (0ct 31-Nov 4) } \\
\text { contact: } \\
\text { Tel: 612-625-1500 } \\
\text { Fax: 612-626-8311 }\end{array}$ & \\
\hline
\end{tabular}


MEETINGS DEADLINES REMINDERS

\section{November}

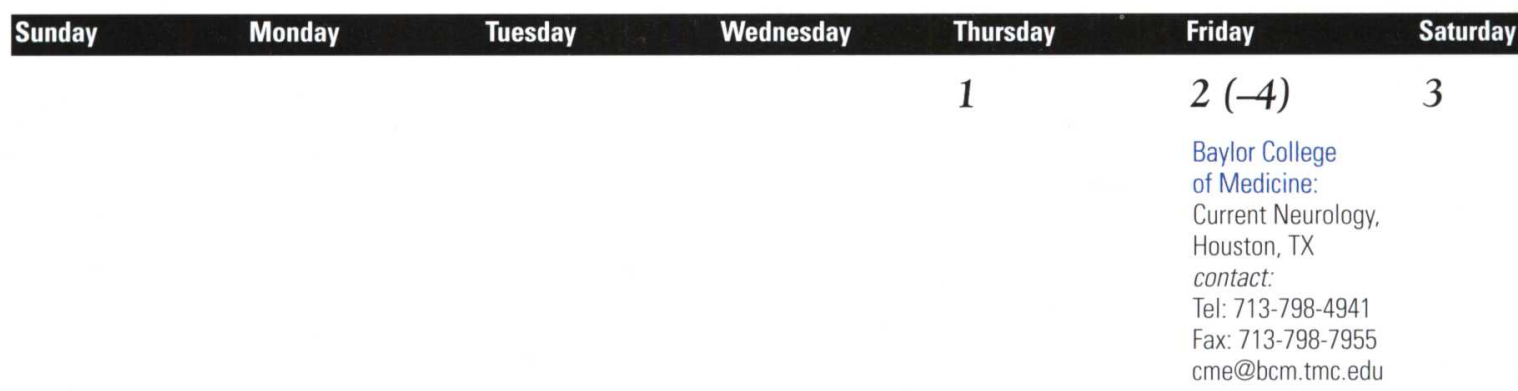

\begin{tabular}{|c|c|c|c|c|c|c|}
\hline \multirow[t]{2}{*}{4} & 5 & 6 & 7 & $8(-9)$ & 9 & $10(-15)$ \\
\hline & & & & $\begin{array}{l}\text { 2nd Neurobiology } \\
\text { of Aging Conference: } \\
\text { San Diego, CA } \\
\text { contact: } \\
\text { Tel: 441-865-794-727 } \\
\text { Fax: 441-865-794-695 } \\
\text { enquiries.oxconf@ } \\
\text { pop3.hiway.co.uk }\end{array}$ & $\begin{array}{l}\text { Neuro-Psychiatry } \\
\text { Update: } \\
\text { Los Angeles,CA } \\
\text { contact: } \\
\text { Tel: 617-572-3597 } \\
\text { Fax:617-859-4354 } \\
\text { npupdates@hhcc.com }\end{array}$ & $\begin{array}{l}\text { 31st Annual Meeting } \\
\text { of the Society for } \\
\text { Neuroscience: } \\
\text { San Diego, CA } \\
\text { contact: } \\
\text { Tel: 202-462-6688 } \\
\text { info@sfn.org }\end{array}$ \\
\hline
\end{tabular}

\begin{tabular}{|c|c|c|c|c|}
\hline 11 & $12(-15)$ & 14 & $15(-18)$ & $17(-19)$ \\
\hline $\begin{array}{l}\text { 2nd World Conference } \\
\text { of Chinese Neurologists: } \\
\text { Hong Kong } \\
\text { (Nov 10-11) } \\
\text { contact: } \\
\text { Tel: 852-2527-8898 } \\
\text { Fax: 852-2866-7530 } \\
\text { cosfmshk@ } \\
\text { netvigator.com }\end{array}$ & $\begin{array}{l}\text { Basic Neuroendoscopy } \\
\text { Course: } \\
\text { Tuttlingen, Germany } \\
\text { contact: } \\
\text { Tel: 497-461-951-015 } \\
\text { Fax: 497-461-952-050 }\end{array}$ & & $\begin{array}{l}\text { 6th Annual Meeting } \\
\text { of Neuro-Oncology: } \\
\text { Washington, DC } \\
\text { contact: } \\
\text { Tel: 713-792-2222 } \\
\text { Fax: 713-794-1724 } \\
\text { meetings@mdaisd1. } \\
\text { mdacc.tmc.edu }\end{array}$ & $\begin{array}{l}\text { World Federation of } \\
\text { Neurosurgical Societies: } \\
\text { Post Graduate Course, } \\
\text { Madras, India } \\
\text { contact: } \\
\text { Tel: } 91-444-364-150 \\
\text { Fax: } 91-444-335-050 \\
\text { kganap@vsnl.com }\end{array}$ \\
\hline
\end{tabular}

\begin{tabular}{|c|c|c|c|c|c|}
\hline \multirow[t]{3}{*}{18} & 19 & 20 & 21 & & 24 \\
\hline & & & & Thanksgiving-USA & \\
\hline & & & & $\begin{array}{l}\text { 7th Mediterranean } \\
\text { Epilepsy Conference: } \\
\text { Athens, Greece } \\
\text { (Nov 22-25) } \\
\text { contact: } \\
\text { Tel: 30-16-889-100 } \\
\text { Fax: 30-16-844-777 } \\
\text { congress@cnc.gr }\end{array}$ & \\
\hline \multirow[t]{2}{*}{25} & 26 & 27 & 28 & 29 & $30(-\operatorname{Dec} 1)$ \\
\hline & & & $\begin{array}{l}\text { December CNS } \\
\text { closes \& ships } \\
\text { to printer }\end{array}$ & $\begin{array}{l}\text { 23rd Annual } \\
\text { Convention of the } \\
\text { Philippine Neurological } \\
\text { Association: } \\
\text { lloilo City, Philippines } \\
\text { (Nov 28-Dec 1) } \\
\text { contact: } \\
\text { Tel: 6-327-232-101 } \\
\text { secretariat@pna.com.ph }\end{array}$ & $\begin{array}{l}\text { National } \\
\text { Neuroscience } \\
\text { Conference: } \\
\text { New York, NY } \\
\text { contact: } \\
\text { Tel: 212-305-3334 } \\
\text { Fax: 212-781-6047 } \\
\text { cme@columbia.edu }\end{array}$ \\
\hline
\end{tabular}


ARICEPT• (Donepezil Hydrochloride Tablets)

Briel Summary - see package insert for full prescribing information. INDICATIONS AND USAGE ARICEPT is indicated for the treatment of mild to moderate dementia of the Alzheimer's lype. CONTRAINDICATIONS ARICEPT is contraindicated in patients with known hypersensitivity to donepezil hydrochloride or to piperidine derivatives. WARNINGS Anesthesia: ARICEPT ${ }^{\oplus}$, as a cholinesterase inhibitor, is likely to exaggerate succinylcholine-type muscle relaxation during anesthesia Cardlovascular Cond/tions: Because of their pharmacological action, cholinesterase inhibitors may have vagotonic effects on the sinoatrial and atrioventricular nodes. This effect may manifest as bradycardia or heart attack in patients both with or without known underlying cardiac conduction abnormalities. Syncopal episodes have been reporied in association with the use of ARICEPT Gastrointestina/ Condthons: Through their primary action, cholinesterase inhibitors may be expected to increase gastric acid secretion due to increased cholinergic activity. Therefore, patients should be monitored closely for symptoms of active or occult gastrointestinal bleeding, especially those at increased risk for developing ulcers, e.g. those with a history of ulcer disease or those receiving concurrent nonsteroidal anti-inflammatory drugs (NSAIDS). Clinical studies of ARICEPT ${ }^{\boxplus}$ have shown no increase, relative to placebo, in the incidence of either peptic ulcer disease or gastrointestinal bleeding. ARICEPT ${ }^{\circ}$, as a predictable consequence of its pharmacological properties, has been shown to produce diarrhea, nausea and vomiting. These effects, when they occur, appear more frequently with the $10 \mathrm{mg} /$ day dose than with the $5 \mathrm{mg} /$ day dose. In most cases, these effects have been mild and transient, sometimes lasting one to three weeks, and have resolved during continued use of ARICEPT ${ }^{*}$. Genifourinary: Although not observed in clinical trials of ARICEPT ${ }^{\circledR}$, cho inomimetics may cause bladder outtlow obstruction. Neurological Condifions: Seizures: Cholinomimetics are believed to have some potential to cause generalized convulsions. However, seizure activity also may be a manifestation of Alzheimer's Disease. Pulmonary Conditions: Because of their cholinomimetic actions, cholinesterase inhibitors should be prescribed with care to patients with a history of asthma or obstructive pulmonary disease. PRECAUTIONS Drug-Drug Interactions Drugs Highly Bound to Plasma Proteins: Drug displacement studies have been performed in vitro between this highly bound orug (96\%) and other drugs such as furosemide, digoxin, and warfarin. ARICEPT ${ }^{*}$ at concentrations of $0.3-10 \mu \mathrm{g} / \mathrm{mL}$ did not affect the binding of furosemide $(5 \mu \mathrm{g} / \mathrm{mL})$, digoxin $(2 \mathrm{ng} / \mathrm{mL})$, and warfarin $(3 \mu \mathrm{g} / \mathrm{mL})$ to human albumin. Similarly, the binding of ARICEPT to human albumin was not affected by furosemide, digoxin, and warfarin. Effect of ARICEPT on the Metabolism of Other Drugs: No in vivo clinical trials have investigated the effect of ARICEPT ${ }^{\star}$ on the clearance of drugs metabolized by CYP $3 \mathrm{A4}$ (e.g. cisapride terfenadine) or by CYP 206 (e g. imipramine). However, in vitro studies show a low rate of binding to these enzymes (mean $\mathrm{K}_{\mathrm{i}}$ about $\left.50-130 \mu \mathrm{M}\right)$, that, given the therapeutic plasma concentrations of donepezil (164 nM), indicates little likelihood of interference. Whether ARICEPI' has any potential for enzyme induction is not known. Effect of Other Drugs on the Metabolism of ARICEPTP: Ketoconazole and quinidine, inhibitors of CYP450, 3A4 and 2D6, respectively, inhibit donepezil metabolism in vitro. Whether there is a clinical effect of these inhibitors is not known. Inducers of CYP $2 D 6$ and CYP $3 A 4$ (e.g. phenytoin, carbarnazepine, dexamethasone, rifampin, and phenobarbital) could increase the rate of elimi iration of ARICEPT Use with Anticholinergics: Because of their mechanism of action, cholinesterase inhibitors have the potential to intertere with the activity of anticholinergic medications. Use with Cholinomimetics and Other Cholinesterase Inhibitors: A synergistic effect may be expected when cholinesterase inhibitors are given concurrently with succinyicholine, similar neuromuscular blocking agents or cholinergic agonists such as bethanechol. Carcinogenesis, Mutagenesis, Impairment of Fertility Carcinogenicily studies of donepezil have not been completed. Donepezil was not mutagenic in the Ames reverse mutation assay in bacteria. In the chromosome aberration test in cuttures of Chinese hamster lung ( $\mathrm{CHL}$ ) cells, some clastogenic effects were observed. Donepezil was not clastogenic in the in wivo mouse micronucleus test. Donepezil had no effect on fertility in rats at doses up to $10 \mathrm{mg} / \mathrm{kg} / \mathrm{day}$ (approximately 8 times the maximum recommended human dose on a mg/m² basis). Pregnancy Pregnancy Category $C$ : Teratology studies conducted in pregnant rats at doses up to $16 \mathrm{mg} / \mathrm{kg} /$ day (approximately 13 times the maximum recommended human dose on a $\mathrm{mg} / \mathrm{m}^{2}$ basis) and in pregnant rabbits at doses up to $10 \mathrm{mg} / \mathrm{kg} / \mathrm{day}$ (approximately 16 times the maximum recommended human dose on a $\mathrm{mg} / \mathrm{m}^{2}$ basis) did not disclose any evidence for a teratogenic potential of donepezil. However, in a study in which pregnant rats were given up to $10 \mathrm{mg} / \mathrm{kg} / \mathrm{day}$ (approximately 8 times the maximum recommended human dose on a mg/m $/ \mathrm{m}^{2}$ basis) from day 17 of gestation through day 20 postpartum, there was a slight increase in still births and a slight decrease in pup survival through day 4 postpartum at this dose; the next lower dose tested was $3 \mathrm{mg} / \mathrm{kg} / \mathrm{day}$ be used during pregnancy only it the potential benefit justifies the potential risk to the fetus. Nursing Mothers It is not known whether donepezil is excreted in human breast milk. ARICEPT has no indication for use in nursing mothers. Pediatric Use There are no adequate and well-controlled trials to document the satety and efficacy of ARICEPT in any iliness occurring in children. ADVERSE REACTIONS Adverse Events Leading to Discontinuation The rates of discontinuation from controlled clinical trials of ARICEPT due to adverse events tor the ARICEPT $5 \mathrm{mg} /$ day treatment groups were comparable to those of placebo-treatment groups at approximately $5 \%$. The rate of discontinuation of patients who received 7 -day escalations from $5 \mathrm{mg} / \mathrm{day}$ to $10 \mathrm{mg} / \mathrm{day}$, was higher at $13 \%$. The most common adverse events leading to discontinuation, detined as those occurring in at least $2 \%$ of patients and at twice the incidence seen in placebo patients, are shown in Table 1.

Table 1. Most Frequent Adverse Events Leading to Withdrawal from Controlled Clinical Trials by Dose Group

\begin{tabular}{lccc}
\hline Dose Group & Placebo & $\mathbf{5 ~} \mathbf{~ m g} /$ day ARICEPT & $\mathbf{1 0} \mathbf{~ m g / d a y ~ A R I C E P T ~}$ \\
$\begin{array}{l}\text { Patients Randomized } \\
\text { Event/\%Discontinuing }\end{array}$ & 355 & 350 & 315 \\
Nausea & $1 \%$ & $1 \%$ & $3 \%$ \\
Diarrhea & $0 \%$ & $<1 \%$ & $3 \%$ \\
Vomiting & $<1 \%$ & $<1 \%$ & $2 \%$ \\
Most & &
\end{tabular}

Most Frequent Adverse Clinical Events Seen in Association with the Use of ARICEPT' The most common adverse are largely predicted by ARICEPT's 's cholinomimetic effects. These include nausea, diarnea, insomnia vomiting, muscle cramp tatigue and anorexia. These adverse events were often of mild intensity and transient, resolving during continued ARICEPT rreatment without the need for dose modification. There is evidence to suggest that the frequency of these common adverse events may be affected by the rate of titration. An open-label study was conducted with 269 patients who received placebo in the 15 - and 30 -week studies. These patients were titrated to a dose of $10 \mathrm{mg} /$ day over a 6 -week period. The rates of commo adverse events were lowes than those seen in patients titrated to $10 \mathrm{mg} /$ day over one week in the controlled clinical trials and were comparable to those seen in patients on $5 \mathrm{mg} /$ day. See Table 2 for a comparison of the most common adverse events following one and six week titration regimens.

Table 2. Comparison of Rates of Adverse Events in Patients Titrated to $10 \mathrm{mg} / \mathrm{day}$ Over 1 and 6 Weeks

\begin{tabular}{lcccc}
\hline Adverse Event & $\begin{array}{c}\text { Placebo } \\
(\mathbf{n = 3 1 5 )}\end{array}$ & $\begin{array}{c}\text { No titration } \\
\mathbf{5} \mathbf{~ m g / d a y} \\
\mathbf{( n = 3 1 1 )}\end{array}$ & $\begin{array}{c}\text { One-week titration } \\
\mathbf{1 0} \mathbf{~ m g / d a y} \\
\mathbf{( n = 3 1 5 )}\end{array}$ & $\begin{array}{c}\text { Six-week titration } \\
\mathbf{1 0} \mathbf{~ m g / d a y} \\
\mathbf{( n = 2 6 9 )}\end{array}$ \\
Nausea & $6 \%$ & $5 \%$ & $19 \%$ & $6 \%$ \\
Diarnhea & $5 \%$ & $8 \%$ & $15 \%$ & $9 \%$ \\
Insomnia & $6 \%$ & $6 \%$ & $14 \%$ & $6 \%$ \\
Fatigue & $3 \%$ & $4 \%$ & $8 \%$ & $3 \%$ \\
Vomiting & $3 \%$ & $3 \%$ & $8 \%$ & $5 \%$ \\
Muscle cramps & $2 \%$ & $6 \%$ & $8 \%$ & $3 \%$ \\
Anorexia & $2 \%$ & $3 \%$ & $7 \%$ & $3 \%$
\end{tabular}

Adverse Events Reported in Controlled Trials The events cited reflect experience gained under closely monitored condition of clinical trials in a highly selected patient population. In actual clinical practice or in other clinical trials, these frequency estimates may not apply, as the conditions of use, reporting behavior, and the kinds of patients treated may differ. Table 3 lists treatment emergent signs and symptoms that were reported in at least $2 \%$ of patients in placebo-contro lled trials who received ARICEPT and for which the rate of occurrence was greater for ARICEPT ${ }^{\oplus}$ assigned than placebo assigned patients. In generat, adverse events occurred more frequently in female patients and with advancing age.

Table 3. Adverse Events Reported in Controlled Clinical Trials In at Least 2\% of Patients Receiving ARICEPT (donepezil HCI) and at a Higher Frequency than Placebo-treated Patlents

\begin{tabular}{lcc}
\hline Body System/Adverse Event & $\begin{array}{c}\text { Placebo } \\
(n=355)\end{array}$ & $\begin{array}{c}\text { ARICEPT } \\
(n=747)\end{array}$ \\
Percent of Patients with any Adverse Event & 72 & 74
\end{tabular}

Body as a Whole

Headache

Pain, various locations

Acciden

Fardigue

Syncope

Digestive System

Nausea
Diarthea

Vomiting

Anorexia

Hemic and Lymphatic System

Ecchymosis

Metabolic and Nutritional Systems

Weight Decrease

Musculoskeletal System

Muscle Cramps

Arthritis

Nervous System

Insomnia

Dizziness

Abnormal Dreams

Somnolence

Urogenital System

Frequent Urination

Other Adverse Events Observed During Clinical Trials ARICEPT has been administered to over 1700 individuals during clinical trials wortdwide. Approximately 1200 of these patients have been treated for at least 3 months and more than 1000 patients have been treated for at least 6 months. Controlled and uncontrolled trials in the United States included approximately 900 patients. In regards to the highest dose of $10 \mathrm{mg} /$ day this population includes 650 patients treated for 3 moniths 475 patients treated for 6 months and 116 patients treated for over 1 year. The range of patient exposure is from 1 to 475 patients treated for 6 months and 116 patients treated for over 1 year. The range of patient exposure is trom 1 to $A \cdot D A Y$ IPT

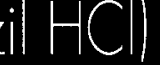

G TABLETS

RMLMBER'

adverse events are not necessarily related to ARICEPT treatment and in most cases were mortant additional adverse eventserved at a similar frequency in placebo-treated patients in the controlled studies. No iniluenza chest pain toothache- Infrequent - fever, edema face, periorbital edema, hernia hiatal, abscess, celliulitis, chills, generalized coldness head fulness, lisilessness. Cardiovascular System: Frequent hypertension, vasodilation, atrial fibrillation, ho flashes, hypotension; Infrequent: angina pectoris, postural hypotension, myocardial infarction, AV block (tirst degree) congestive heart failure, arteritis, bradycardia, peripheral vascular disease, supraventricular lachycardia, deep vein thrombosis. Digestive System: Frequent: fecal incontinence, gastrointestinal bleeding, bloating, epigastric pain; Infrequent: eructation, gingivitis, increased appetile, flatulence, periodontal abscess, cholelithiasis, diverticultits, drooling, dry mouth, fever sore, gastritis, irritable colon,

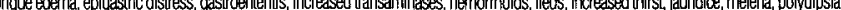
duodenal uicer, stomach ulcer. Endocrine System: Inirequent: diabetes mellitus goiter. Hemic and Lymphatic System: Intrequent anemia thrombocythemia, thrombocytopenia, eosinophilia, enthroctopenia. Metaholic and Nutritional Disorders: Freauent. (a)

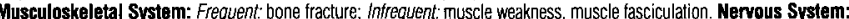
Frequent del usions, tremor irritability, paresthesia, aggression vertigo ataxia increased libido restlessness, abnormal crying nervousness, aphasia: Infrequent: cerebrovascular accident, intracranial hemormage, transient ischemic attack, emotional lability, neuralgia, coldness (localized), muscle spasm, dysphoria, gait abnormality, hypertonia, hypokinesia, neurodermaitis, numbriess (localized), paranoia, dysarthria, dysphasia, hostility, decreased libido, melancholia, emotional withdrawal, nystagmus, pacing. Respiratory System: Frequent: dyspnea, sore throat, bronchitis; Infrequent: epistaxis, post nasal drio pneumonia, hyperventiliation, pulmonary congestion, wheezing, hypoxia, pharyngitis, pleurisy, pulmonary collapse, sleepo apnea, snoring. Skin and Appendages: Frequent: pruritus, diaphoresis, urticaria; Infrequent: dermatitis, enthema, skin discoloration,

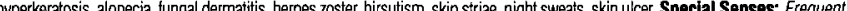
gra

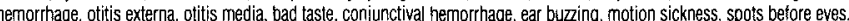
Urogenital System: Frequent: urinary incontinence, nocturia; Infrequent: dysuria, hematuria, urinary urgency, metrorrhagia, cystitis, enuresis, prostate hypertrophy, pyeionephritis, inability to empty bladder, bfeast fibroadenosis, fibrocystic breast, masitis pyuria, renal tailure, vaginitis. Postintroduction Reports voluntary reports of adverse events temporally associated with ARICEPT that have been received since market introduction that are not listed above, and that there is inadequate data to determine the causal relationship with the drug include the following: abdominal pain, agitation, cholecystitis, contusion, convulsions, hallucinations, heart block (all types), hemolytic anemia, hepatitis, hyponatremia, pancreatitis, and rash OVERDOSAGE Because stralegies for the management of overdose are continualiy evolving, it is advisable to contact a Poison Control Center to determine the latest recommendations for the management of an overdose of any drug. As in any case of overdose general supportive measures should be utilized. Overdosage with cholinesterase inhibitors can result in chol inergic

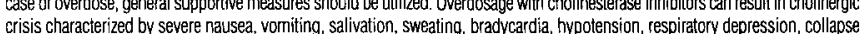
crisis characterized by severe nausea, vomiting, salivation, sweating, bradycardia, hypotension, respiratcry depression, collapse
and convulsions. Increasing muscle weakness is a possibility and may result in death if respiratory muscles are involved. Tertiary and convulsions. Increasing muscle weakness is a possibility and may result in death if respiratory muscles are involved. Tertlary anticholinergics such as atropine may be used as an antidote for ARICEPT ${ }^{\circledast}$ overdosage. Intravenous atropine sulfate titrated to effect is recommended. an inithere date have been reported with other cholinomimetics when co-administered with quaternary antichol inergics such as glycopyrrolate, It is not known whether ARICEPT and/or its metabolites can be removed by dialysis (hemodialysis, peritoneal dialysis or hemofiltration). Dose-related signs of toxicity in animals included reduced spontaneous movenent, prone position, stagoering oait lacrimation, clonic convulsions, depressed respiration, salivation, mon tous shown to be effective in controlied clinical trials are $5 \mathrm{mg}$ and $10 \mathrm{mg}$ administered once per day. The higher dose of $10 \mathrm{mg}$ did not provide a statistically significantly greater clinical benefit than $5 \mathrm{mg}$. There is a suggestion, however, based upon order of group mean scores and dose trend analyses of data from these clinical trials, that a daily dose of $10 \mathrm{mg}$ of ARICEPT migh provide additional benefit for some patients. Accordingly, whether of not to employ a dose of $10 \mathrm{mg}$ is a matter of prescriber and patient preterence. Evidence from the controlled trials indicates that the $10 \mathrm{mg}$ dose, with a one week titration, is likely to be associated with a higher incidence of cholinergic adverse events than the $5 \mathrm{mg}$ dose. In open label trials using a 6 week betration, the frequency of these same adverse event was similar betwe the $5 \mathrm{mg}$ and $10 \mathrm{mg}$ dose groups. Theretore because steady state is not achieved for 15 days and because the incidence of untoward effects may be influenced by the rate of dose conter a treatment with a dose of $10 \mathrm{mg}$ should not be contemplat until patients have been on a daily dose of $5 \mathrm{mg}$ for 4 to 6 weeks. ARICEPT should be taken in the evening, just prior to retiring, and may be taken with or without food. 


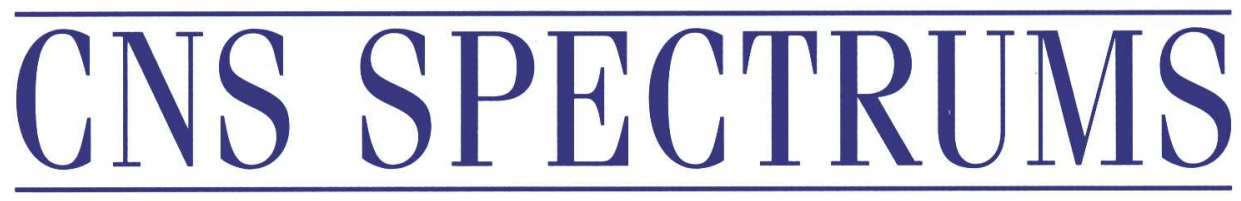

The International Journal of Neuropsychiatric Medicine

EDITOR

Jack M. Gorman, MD

College of Physicians and

Surgeons, Columbia University

New York, NY

\section{INTERNATIONAL EDITOR}

Joseph Zohar, MD

Chaím Sheba Medical Center

Tel Aviv, Israel

\section{ASSOCIATE INTERNATIONAL EDITORS}

EUROPE

Donatella Marazziti, MD

University of Pisa

Pisa, Italy

\section{MID-ATLANTIC}

Dan J. Stein, MB

University of Stellenbosch

Tygerberg, South Africa

\section{FAR EAST}

Shigeto Yamawaki, MD, PhD

Hiroshima University School of

Medicine

Hiroshima, Japan

\section{EDITORIAL DIRECTOR}

James M. La Rossa Jr.

FOUNDING EDITOR

Eric Hollander, MD

\section{BOARD OF ADVISORS}

Margaret Altemus, MD

Cornell University Medical Center

Mitchell F. Brin, MD

Mount Sinai School of Medicine New York, NY

Dennis S. Charney, MD

Yale University

New Haven, CT

Jeffrey L. Cummings, MD

University of California

Los Angeles, CA

Dwight L. Evans, MD

University of Pennsylvania

Philadelphia, PA

Mark George, MD

Medical University of South Carolina

Charleston, SC

Thomas R. Insel, MD

Yerkes Primate Labs Atlanta, GA

Lorrin M. Koran, MD

Stanford University Medical School

Stanford, CA

Herbert Y. Meltzer, MD

Vanderbilt University Medical Center

Nashville, TN

Stuart A. Montgomery, MD

St. Mary's Hospital Medical School

London, United Kingdom

Dennis L. Murphy, MD

National Institute of Mental Health

Bethesda, MD New York, NY

Emory University School of Medicine

Charles B. Nemeroff, MD, PhD

Emory University School of Medicine Atlanta, GA

Humberto Nicolini, MD, PhD

Instituto Mexicano de Psiquiatria

Mexico

Katharine Phillips, MD

Brown University

Providence, RI

Harold A. Pincus, MD

University of Pittsburgh

Pittsburgh, PA

Scott L. Rauch, MD

Massachusetts General Hospital

Charlestown, MA

Alan Schatzberg, MD

Stanford University Medical School

Stanford, CA

Norman Sussman, MD

New York University Medical School New York, NY

Neal R. Swerdlow, MD, PhD

University of California, San Diego

La Jolla, CA

Michael R. Trimble, MD

National Hospital for Neurology

and Neurosurgery

London, United Kingdom

Herman G.M. Westenberg, MD

University Hospital Utrecht

Utrecht, The Netherlands

Richard Wyatt, MD

National Institute of Mental Health

Bethesda, MD

Stuart Yudofsky, MD

Baylor College of Medicine

Houston, TX

CORPORATION COUNSEL

Kevin F. Saer, Esq.

Davis, Wright \& Tremaine

Deborah Hughes

Christopher Naccari

José R. Ralat

PRODUCTION COORDINATOR

Jesse D. Soll

PRODUCTION ASSISTANT

Mark Unterberger

ASSISTANT TO THE PUBLISHER

Lowell Yaeger

ASSISTANT ART DIRECTOR

Benjamin Balcomb

COPY EDITORS

Ava Albrecht, MD

Clinton Corbett

Stephanie Kawada

Meg Phelan

ADMINISTRATIVE ASSISTANT

Claudette Crawford

CONTROLLER

David Windsor
DIRECTOR OF ADVERTISING SALES

Darren L. Brodeur

DIRECTOR, ONCOLOGY SALES

Paul McDaniel

NATIONAL ACCOUNTS MANAGER-

EMERGING MARKETS

Dena M. Trakes

NATIONAL ACCOUNTS MANAGER-

BROADCAST MEDIA

Christopher Van Denburg

ASSOCIATE SALES MANAGER-

LATIN AMERICA

James Kassaris

PUBLISHER \& FOUNDER

James M. La Rossa Jr. 


\section{CNS Digest \\ In the Journal of September 2001}

\section{SEIZURES AND EPILEPSY: CLASSIFICATION AND DIAGNOSIS \\ page 750}

"An important distinction must be made between seizures and epilepsy, which is the underlying condition characterized by recurrent unprovoked seizures. There are several well-recognized epilepsy syndromes, some of which are considered idiopathic, with an underlying presumed genetic etiology. These syndromes tend to be characterized by specific types of seizures, and often by a typical pattern on electroencephalography... The symptomatic epilepsies have an underlying structural or metabolic cause. Review of these common structural etiologies and appropriate diagnostic evaluations are important not only for the identification of potentially dangerous conditions, but also because curative epilepsy surgery is now an option for many patients."

\section{NOVEL ANTIEPILEPTICS FOR THE NEW MILLENNIUM \\ page 756}

"Drug interactions and the effects of systemic disease on AED disposition are complicated, particularly with the older AEDs. Most of these interactions arise from hepatic induction or inhibition, with consequent alteration of drug half-life. In general, drugs that induce hepatic enzymes will increase the metabolism and decrease the serum concentration of other drugs that are hepatically metabolized. Other interactions, such as increased free fraction of drug, occur when highly plasma-bound agents (phenytoin, valproate, tiagabine) are coadministered... Because they neither cause hepatic induction nor are appreciably affected by it, gabapentin and levetiracetam have virtually no drug-drug interactions. Lamotrigine, topiramate, zonisamide, and tiagabine have little or no effect on other drugs, but their levels can be reduced when given with enzyme inducers. It is nearly impossible to know all pharmacokinetic drug-drug interactions, and, therefore, this information must be researched whenever there is a question. Pharmacodynamic interactions may also occur, which will affect drug action and adverse effects, but not plasma levels."

\section{NEUROSURGERY, LENNOX-GASTAUT SYNDROME, AND THE VNS PATIENT REGISTRY page 766}

"Patients with LGS have seizures that are largely resistant to medical therapy. In studies involving older antiepileptic medications, only $6.7 \%$ to $13.7 \%$ achieve freedom from seizures. Some of the newer antiepileptic medications (lamotrigine, topiramate, and felbamate) have been studied in the treatment of LGS. The rate of seizure freedom for the newer antiseizure agents was not significantly better than that for the older antiepileptic medications. The ketogenic diet is effective in children with refractory epilepsy, including LGS, and may provide complete seizure control in up to $20 \%$ to $30 \%$ of patients. ${ }^{9}$ However, the diet is difficult to maintain and causes metabolic acidosis, recurrent infections, anorexia, and renal stones in up to $5 \%$ of patients."

\section{REPRODUCTIVE DYSFUNCTION AND AEDS IN WOMEN \\ page 771}

"Whether infertility is a consequence of the social and psychological disability often accompanying epilepsy, an effect of seizures and epilepsy on physiological systems supporting reproductive health, or an adverse effect of AEDs, has been debated. Most likely, the causes of reduced birth rates are multifactorial. In the past, women with epilepsy may have been at a social disadvantage; however, the marriage rate for women with epilepsy in the United States is now equivalent to that of the general population. Certainly, women with epilepsy may choose not to become parents, perhaps because of concern about the teratogenic risks of AEDs or because they feel seizures may cause too many parenting difficulties."

\section{COGNITIVE DIFFICULTIES IN ABUSED WOMEN page 787}

"Analysis of variance (ANOVA) was used to examine group comparisons among the nonabused $(n=22)$, IPV without PTSD (PTSD-; $n=21$ ), and IPV with PTSD (PTSD+; $\mathrm{n}=20$ ) groups (Table 1) on self-perceived cognitive difficulties and depression. Post-hoc analyses were conducted with the Tukey test, except when the assumption of homogeneity of variance was violated, in which case Tamhane's T2 was used. Pearson product moment correlations were used to examine the relationships between self-perceived cognitive difficulties and measures of psychological functioning, including severity of PTSD symptoms, severity of depressive symptoms, and daily functioning. A hierarchic regression, controlling for the effects of depression, was also performed on the data to examine the predictive power of PTSD severity on CDS scores. To investigate whether the severity of abuse could predict self-perceived cognitive dysfunction, a stepwise regression was performed, with the psychological aggression, physical assault, sexual coercion, and injury subscales of the CTS-2 as the independent variables and the CDS as the dependent variable. PTSD+ and PTSD-group differences in sexual trauma were examined using the $\chi^{2}$ test, and ANOVA was performed using the same groups to determine differences in nonsexual assaultative and nonassaultative traumas. Two-tailed tests were used throughout, and $\alpha$ values $<0.05$ were considered statistically significant." 
Reference: 1. Pollack MH, Marzol PC. Pharmacotherapeutic options in the treatment of comorbid depression and anxiety. CNS Spectrums. December 2000;5:23-30.

ZOLOFT is indicated for the treatment of major depression, panic disorder, PTSD, and obsessions and compulsions in patients with $O C D$, and can be used in pediatric patients (aged 6 to 17 years) with OCD. The most common side effects in adults with depression and other premarketing controlled trials, OCD, panic disorder, or PTSD include nausea, insomnia, diarrhea, dry mouth, ejaculation failure (primarily ejaculatory delay), somnolence, fatigue, tremor, dyspepsia, libido decreased, increased sweating, anorexia, and agitation. In pediatric patients, the overall profile of adverse events was similar to that of adults. However, the following events were also reported: hyperkinesia, twitching, fever, malaise, purpura, weight decrease, concentration impaired, manic reaction, emotional lability, thinking abnormal, and epistaxis. ZOLOFT is available in $25 \mathrm{mg}, 50 \mathrm{mg}$, and $100 \mathrm{mg}$ tablets.

BRIEF SUMmaRY. Consult the packege insert for complete prescribing informetion.

CONTRAINDICATIONS: Concomitont use in potients toking monoornine oxidose intibitors (MAOls) is controindicoted. WARNINGS: Coses of serlows sometimes fotd reactions hove been reperted in patients receiving ZOLOFT in combination with with an MAOI. Similaty, at least 14 days should be allowed ofter stopping ZOLOFT before sterting an MMOI. PRECAUTIONS: Genera/ - Adivation of Memia/Hypomonia - During premparketing testing, hypontanio or manio occurred in approximately $0.4 \%$ of 20 LOFT-treated patiens. Woight Loss - Significant weight loss may be on undesiroble result of treatment with sertraline for some patients, but on average, patients in controlled trials had minimol, 1 to 2 pound weight loss. Soizure - 70lOF hes not bean evaluated in patients with a seizuse disorder. ZOLOFT should be introduced with care in petients with a seizure disorder. Suldde - The possibility of a sujade attempt is inherent in depression and mey persist unit significant remission occurs. Close supervision of high risk patients should accompony initiol drug therapy. Prescriptions tor ZOLOFT should be witten for the smallest quantity of tablets

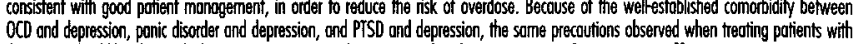
OCD and depression, penic disorder and depression, and PTSD and depression, the Same preccutions observed when treating patients with
depression should be observed when treating potients with OCD, panic disorder, or PTSD. Weak Uricosuric Effiect - ZOLOF is assaciated with o meon deceanse in senum uric acid of opproximately $7 \%$. The clinical significance of this weak uricosuric effect is unknown. Use in Potients with Concomitont liness - Clinical experience with 20 LOFI in patients with certoin concomitgnt systemic illness is limited. Use cautiously in potients with diserses or condtions that could offect metabolism or hemodynamic responses. 20 LOFT has not been evaluated or used to ony appreciable extent in patients with a recent history of myocordial infarction or unstoble heort diseose. In patients with chronic mild liver impoiment, serrtaline cloaronce was reduced, thus increasing AUC, $C_{\mathrm{max}}$ and elimination haff-iffe. Effects in potients with moderote and severe hepatic impairment have not been studied. Approach the use of sertraline with coution in patients with liver diseose, and use a lower or less frequent dose in patients with liver impoirment. Since ZOLOFT is extensively metobolized, excretion of unchonged duvg in urine is a minor route of elimination. A clinical study has indicoted that renal disease does not offect sertroline phormacokinetics ond protein binding. Therefore, no dosage odjustment is needed in potients with renal impoirment. Inferference with Cognifive ond Motor Performance- in controlled shudies, ZOLOFT did not cause sedation and did not interfere with psychomotor performance. Hyponeitremia - Several coses of reversible hyponotrennio hove been reportied, mostly in elderly individuals with some raking diuretios or who were otherwise volume depleted. Platclot function - There hove been rare repocts of atered plotelet tunction and/or obnormal results from loborotory studies in potients taking 2010FT. While there hove been reports of abnormal bleeding or purpura in several patients toking $20 \mathrm{LOF}$ it is undear whather 20 LOFT had o cousative role. Information for Pationts: Physidion are odvised to discuss the following issues with patients for whom they prescribe 20LOF: Patients should be told thot olthough zOLOFT has not been shown to impair the ability of normal subjects to perform tasks requiring complex motor and mental skills in loboratory advesely. Therefore, potients stould be todd that unitil they leam how they respond to $2010 \mathrm{FT}$ they should be coreful doing activities when they need to be alest, such as driving a cor or operating machinery. Potiants should be told that dithough ZOL. OFT has not been shown in experinents with normal subjects to inceesse the mental ond motor skill impoiments caused by dicohol, the concomitiont use of $2010 \mathrm{FT}$ and alchol is not advised. Patients should be told that while no adverse interaction of $2010 \mathrm{~F}$ w with over the-counter (0TC) drug products is known to occur, the potential for interaction exists. Thus, the use of any OIC product should be initioted cautiously according to the directions of use given for the OTC product. Potients should be advised to netify their physicion if they become pregnont or intend to

become pregnant during therapy. Patients should be advised to notify their physican if they are breostfeeding on infunt. Drug interactions Potential Effects of Coodninistralion of Drugs Highly Bound to Plasma Protains - Adverse effects may result from displocement of proteintbound 20LDF by other tightly bound drugs, eg, warforin, digitoxin. Prothrombin time should be carefully monitored

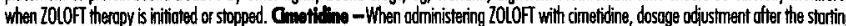
dose of 50 mg should be guided by clinical effect. CNS Active Drugs - Concomitont use of Z0LOF with diazepam or desmethydiazepom may require dosoge odjustment. Even though lithium levels were not oftered in dinical tricls, it is recommended that plasma lithium levels be monitored following intiation of ZOLOFT thercopy with oppropriate adiustments to the lithium dose. The risk of using ZOLOFT in combination

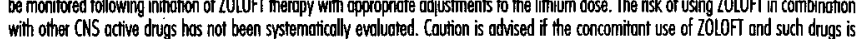

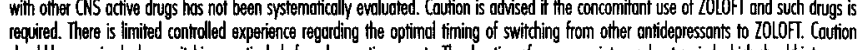
should be exectised when switching, partiaulanty from long-acting ogents. The duration of an appropiote woshout period which should intervene before swithing from one selective serotonin reuptake inhilititor (SSRI) to another hos not been estrablished. Drugs Melabolized by P450 $3 A 4$ - In two separate in wivo interaction studies, sertraline was condministered with the cytochrome P450 $3 \mathrm{A4}$ substrates torfenadine or corbamazepine, under steady-state conditions. The results of thase studies demonstated that sertraline coodministrotion did not increass plasma concentrotions of terfenotine or cabamazepine. These dato suggest that sertraline's extent of intibition of P450 $3 \mathrm{A4}$ activity is not likely to be of dinical significance. Drugs Metabolized by P450 2D6 - Many antidepressants, eg, the SSRIs, including sertroline, and most tricyclic antidepressants inhibit the biochemical activity of the drug metobolizing isozyme cytochrome $\mathrm{P} 450206$ (debrisoquin hydroxylase), ond, thus, moy increosse the plasma concentrations of condministered drugs that are metabolized by P450 206. This potential interction is of grectest concem in those drugs metabolized primarily by 206 and which have o nanow therapeutic index, eq, the tricydic antidepressants (TCAs) and the Type IC anticurntyhtmics propofenone and flecainide. The extent to which this interaction is an

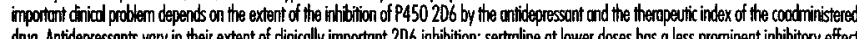
drug. Antididepressants vary in their extent of dinicaly inports

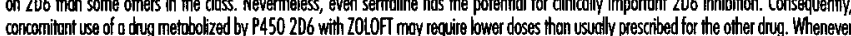

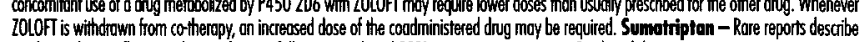
weakness, hyperreflexia, and incoordination following combined SSRL-sumatipipton treatment. Combined therapy worrants appropiote potient observation. TCAs - Caution is indicated in the coadministration of ICAs with ZOLOFT, bectouse sertraline may inhibit TCA metabolism. The extent to which SSRHFCA internctions may pose clinical problems depends on the degree of inhibition and the phomocokinetics of the SSR involved. Plosmo TCA concentrations moy need to be monitored, and the dose of TCA may need to be reduced, if a ICA is co-administered

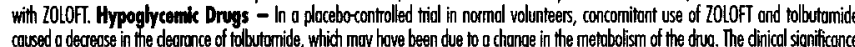

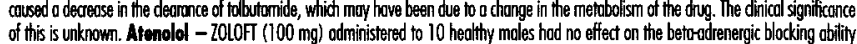

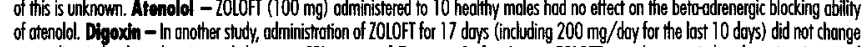
serum digoxin leves or digoxin renai clearonce. Microsomal Enzyme Induction - $20 \mathrm{LOFT}$ wos shown to induce hepatic microsomo enzyrnes, as determined by a deccesese in antipyine half-iffe. This small change reflects a clinically insignificant change in hepacic metabolism. Eloctroconvulsive Therapy (ECT) - There are no dinical studies estoblishing the isks or benefits of the combined use of $E C$ and ZOLOFT. Akohol - Although ZOLOFT did not potentiate the cognitive and psychomotor effects of alcohol in dinical studies, the concomitan use of $7010 \mathrm{FT}$ and akchol is not recommended. Carcinegenesis, Mutagenesis, Impairment of Ferthity: Lifetime carcinogenicity studes corried out in mice ond rats showed a dosereloted increose of liver odenomos in mole mice receiving sertroline at $10-40 \mathrm{mg} / \mathrm{kg}$

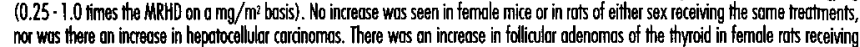
sertrating of $40 \mathrm{mg} / \mathrm{kg}$. While there was on increase in uterine adenocorainomas in rots receiving sertraline of $10-40 \mathrm{mg} / \mathrm{kg}$, this effect wos not dootiy drug reateded. Sertrdine had no genotoxic effects, with or without metobolic octivation, based on loboratory assoys. A decreose in fertitity was seen in one of two rot studies of a dose of $80 \mathrm{mg} / \mathrm{kg}$ (4 times the maximum humon dose on a mg/mi basis). PregnencyProgenoncy Cotagary C: There are no odequate and well-contronled studies in pregnant women. Z0lOFT should be used during pregnancy only if the potentiol benefit justifies the potentiad risk to the fehus. Laber and Delivery - The effect of $2010 \mathrm{~F}$ on lebor and delivery in humans is unknown. Mursing Hothers - It is not known whether serroline or its metobolites ore excreted in human milk. Becouse many dnugs ore exceted in human milk, caution should be exercised when 20LOFT is odministered to a nursing woman. Pediatric Use - I pediantic patients agad 6 to 17 years, drug exposure wos generally similar to that of adults, when phasmo concentrotions were adiusted for weight. The effectiveness of 20LOFT in pediatic potients with depression or panic disorder has not been systematically evaluated. Regular manitoning of weight and growth is recommended. The nisks, ff ony, thot may be associoted with the extended use of 2OLOFT in children

and addescents with OCD hove not been systematically assessed. There are no studies that diroctly evaluate the effocts of longtarm use of sertraline on the growth, development, and motustion of chiddren and adolescents. Although there is no affirmative finding for suct affects, in potients $\geq 65$ years of oge revealed no overall differences in poltern of efficocy or odverse reactions relative to younger potients except for urinary tract infection (incidence $\geq 2 \%$ ond greater thein placebo). As with all medications, greater sensitivity of some older individuats cannot be ruled out. As with other SSRIs, 20LOFT has been ossociated with cases of dinically significant hypongtemionio in elderty potients. ADVERSE REACTIONS: Incidence in Placebo-Controliod Cinical Trids - Mlost Common Ireatment-Emergent Adrorse Events: The most common adverse events reported ir adult patients receiving Z0LOFT (N=2198; $N=1877$ for plocebo) for the theotment of depression/other, OCD, panic disorcter, and PTSD combined in controlled trials (incidence $2 \%$ or more for $70 \mathrm{LOFI}$ and greater then placebo): Autonomic Nervous System Disorders - ejaculatory failure ([primarily ejoculatory delay; denominator used for male patients only] $4 \%[n=9] 3]$ us $1 \%[n=773])$, mouth dy (15\% vs $9 \%$ ), swedting increased (6\% vs 2\%). Central \& Perlpherd Nervous Systom

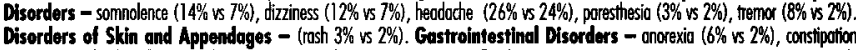

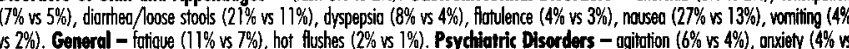

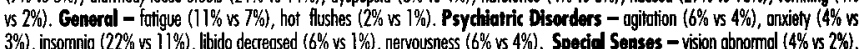
Adverse Events in Pedfiatric Patients: In pediattic patients $(n=187$ ), the overall profile was similar to that of adults. However, the following events were also reported (indidence of $\geq 2 \%$ and at leost twice thot of placebo): hyperkinesia, twitching, fever, maloise, pupuro, weight decrease, concentration impoired, manic reaction, emotional lability, thinking abnormal, and epistoxis. Assodated What Discontiousation of Ireatments The ndverse events ossacioted with discontinuation of 701 OFT treatment (incidence of leass twice thot

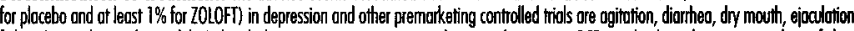

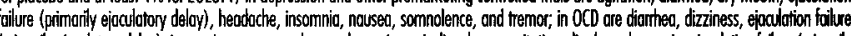

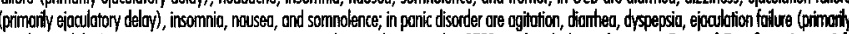
ejoculatory delay), insomnia, nausea, nervousness, and somnolence; and in PTSD are headache and nouseo. Sexwal Dysfunction with SSRls: Although sexual desire, sexual performance, ond sexual satisfaction may change as a monifestation of psychiontic disorders, som vidence suggests that SSRis may cause untoward sexual expeniences. Relicble estimates accordingly, product labeling is likely to underestimate their octual incidence. There are no accordingly, product labeing is likely to underestimate their actual incidence. These are no
adequate, wellecontrolled studies of sexud dysfunction with sertraline. Priopism has been reported with all SSRls. Physicions should routinely inquire about possible sexud side effects in patients toking SSRls. Other Events Ots served During the Premarkefthe administered to opproximotely 4000 odult subjects. Events are turther cortegorized by boty system ond listed in order of decreasing frequency. Note: frequent=events occurring in of least $1 / 100$ potients; infrequent=l/1000 patients; rare=less than $1 / 1000$ patients. It is

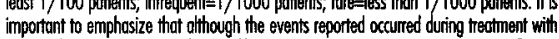

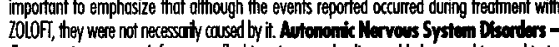
Frequent impotence; I Intequent: flushing, increased salivo, cold daminy skin, myddiosis;

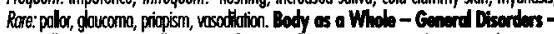
Rore: ollergic reoction, allergy. Certiovoscular - Frequent, palpitations, hesst pain infrequent hyperentension, tochycardia, postural dizziness, posturol hypotension, periotitiol Intequent hypertension, tochycardia, postural dizziness, posturol hypotension, perioutrol edema; Rare: precordial chest pein, substernal chest pain, aggrovated hypertension, myocandial inforction, cerebebrovosaltar disorder. Centre and Peripheral Nervous System Disorders - Frequent: hyperionio, hypoesthesia; Infrequent: Wwitching, contusion, hypenkinesio, vertigo, atoxia, migroine, abnormal coordination, hyperesthesio, leg cramps, obnormal gait, nystugrnus, hypokinesia; Rare: dysphonio, como, dyskinesia, hypotonia, ptosis, doreoathetosis, hyporeflexis. Disorders of Stin and Appendenes - Infreavent: pruilus, ocne, urticorio, alopecia, dry skin, erythemetous rosh, photosensitivity recction, maculopapular rash; Rare: follicular rosh, eczema, dermatitis, contoc

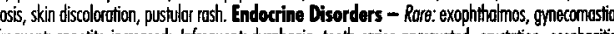
Gastrointestinal Disorders - Frequent: appeite increased; infrequent: dysphogia, tooth canies aggrovoted, enuctution, escophogitis,

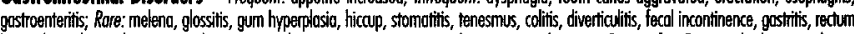

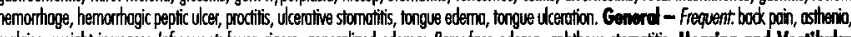
malaise, weight inaease; Intrequent, fever, nigors, generalized edema; Rare: foce edema, aphthous stomatitis. Hearing and Vositbulew

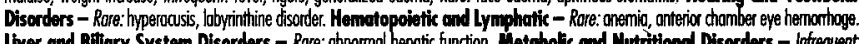
Liver and Befliary System Disorders - Rare: abnormal hepatic function. Metabolis and Mutritional Disorders - Infrequent.

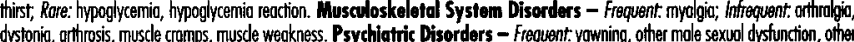

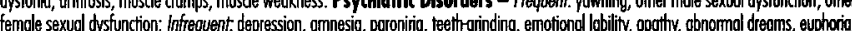
paranoid reaction, hallucination, aggesssive reaction, aggravated depression, delusions; Rare: withdrowal symdiome, suicide ideation, libido increased, somnambulism, illusion. Reproductive - Infrequent: menstrual disorder, dysmenorthea, intermenstual bleeding, vaginol hemorhage, amenornhea, leukorthea; Rare: Female breast pain, menorhagia, bolanoposthitis, breess enlargement, otrophic vaginitis, aat female mastilis. Respiratory System Bisorders - Frequent: thinitis; Infrequent: coughing, dyspnea, upper respingotory tract infection, epistaxis, bronchosposm, sinusitis; Rore: hyperventilation, brodypnea, stridor, opnea, bronditis, hemoptysis, hypoventilotion, laryngismus,

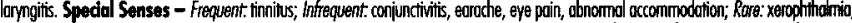
photophobia, diphopia, abnomal lacination, scotomo, visual field defect. Unrinury System Disorders - Infrequent: micturition frequency

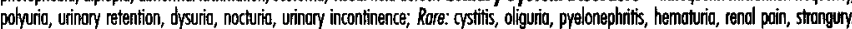
Laboratory Tests: Asymptomatic elevations in serum transaminoses (SGOT [or AST] ond SGPT (or ALT) have been reported intrequentif (approximotely $0.8 \%$ ). Hepatic enzyme elevations usually occured within the first 1 to 9 weeks of treatment and promply dininished upon drug discontinuation. 70lOFI therapy was associated with smoll mean increases in total dolesterol (opproximately 3\%) and trighkerides (approximately 5\%), and a small mean decrease in serum uric acid (approximately $7 \%$ ) of no apparent dinical importonce. The sofery protile observed with ZOLOFT Treotment in potients with depression, OCD, panic disorder, and PTSD is similor. Other Events Observad Durhy the Postmarketing Evaluation of ZOLOFT: Reports of adverse events received since market introduction thot are not listed obove

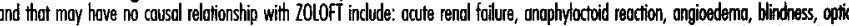

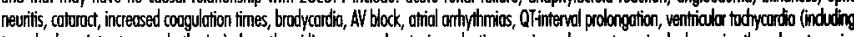
forsade de pointes-type anthytmias), hypothyoidlism, agronulocytosis, aplastic anemia ond pancyoperiic, leukopenio, thrombocytopenia, lupustike syndrome, serum sickness, hypergilycemia, galactornhea, hyperprolactinemia, neuroleptic malignent syndromelike events, exrrappromidal symptorns, oulogyric crisis, serotonin syndrome, psychosis, pulmonary hypertension, severe skin reoctions, which potentially can be fatal, such os Stevens-Johnson syndrome, vasaulitis, photosensitivity and other severe ataneous disorders, rove reports of panaedutitis, ond liver events - clinicol fectures (which in the majority of coses appenred to be reversible with discontinuotion of 20LOFT) occurring in one or more potients indude: elevoted enzymes, iricreased bilirubin, hepotornegoly, hepatiins, joundice, abdominal pain, vomiting, liver foulure and death. DRUG ABUSE AND DEPENDENCE: Controllod Substance Cass - 2OLOF is not a contolled substance. Premarketing dinical experience with 20L $0 \mathrm{HI}$ did not reveal any tendency for 0 withdrawol syndrome or any dug seeking behavior. Physicions, however,

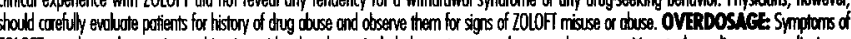
ZOLOFT overdose, alone or in combination with other drugs, induded, most cornmonly, somnolence, vomiting, toctycardia, nausen, dizziness, ogitation, and tremor. Other important adverse events included brodycandia, bundle brand blod, coma, comuksions, delinum, halucinotions, hypertension, hypotension, monic reaction, pancreatitis, QTintervol prolongation, serotonin syndrome, stupor, and syncope. Reports of death airwey, oxygenation, and vertiliction. Gestric lovage with oppropinate aimwoy protection, may be indicated. haduction of emesis is not recommended.

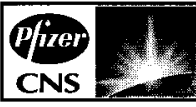




\section{Mood and anxiety disorders have symptoms that overlap}

\section{Depression? Anxiety?}

\section{Treatment: ZOLOFT}

The \#1 Prescribed SSRI in New Rxs and Total RxS

Indicated for: Major depression

\section{Panic disorder}

Obsessive-compulsive disorder (OCD)

-adult

-pediatric

-IMS America National Prescription Audit, May 2001.

ZOLOFT is contraindicated until at least 14 days have passed since discontinuing a monoamine oxidase inhibitor (MAOI) and an MAOI is contraindicated for at least 14 days after discontinuation of ZOLOFT (see WARNINGS in prescribing information).

Posttraumatic stress disorder (PTSD)

\section{POWER THAT} SPEAKS SOFTLY 
$\overline{\text { CNS SPECTRUMS }}^{\circ}$

The International Journal of

Neuropsychiatric Medicine

Volume 6 - Number 9

September 2001
750 Seizure Types, Epilepsy Syndromes, Etiology, and Diagnosis

By Jonathan C. Edwards, MD

756 Antiepileptic Drugs in the 21st Century

By Carl W. Bazil, MD, PhD

766 Vagus Nerve Stimulation and Lennox-Gastaut Syndrome: A Review of the Literature and Data From the VNS Patient Registry - ORIGINAL RESEARCH

By Steven Karceski, MD

771 Reproductive Dysfunction in Women With Epilepsy: Antiepileptic Drug Effects on Sex-Steroid Hormones -ORIGINAL RESEARCH

By Martha J. Morrell, MD, Kerry L. Flynn, MA, Cairn G. Seale, MS, Silvia Doñe, BA, Amelia J. Paulson, BS, Edith R. Flaster, MS, and Michel Ferin, MD

787 Cognitive Difficulties and Posttraumatic Stress Disorder in Female Victims of Intimate Partner Violence - ORIGINAL RESEARCH

By Colleen M. Kennedy, PhD, Leila Tarokh, BA, and Murray B. Stein, MD
CNS Spectrums is a peer review journal and is indexed in EMBASE/Excerpta Medica, DIALOG, SilverPlatter, OVID, and Lexis-Nexis. CNS Spectrums is endorsed by, and is the official journal of, the International Neuropsychiatric Assoc., with members in 30 countries.

\section{CNS Spectrums}

(ISSN 1092-8529)

is published monthly by

MedWorks Media,

333 Hudson Street, 7th Floor

New York, NY 10013.

Periodicals postage paid at New York, NY, and at additional mailing offices.

One year subscription rates: domestic \$90;

foreign $\$ 145$;

in-training $\$ 50$.

For subscriptions:

Fax: 212-328-0600

E-mail:

jrr@medworksmedia.com

Postmaster:

Send address changes to CNS Spectrums

clo PPS Medical Marketing Group

264 Passaic Ave.

Fairview, NJ 07004-2595 
$\overline{\text { CNS SPECTRUMS }}$

The International Journal of

Neuropsychiatric Medicine

Volume 6 - Number 9 September 2001

\section{Table of Contents}

Departments/Monthly Columns

740 Bridging the Gap: Neurology, Psychiatry, and Women's Health By Jack M. Gorman, MD

\section{CNS NEWS}

741 Briefs From the Fields of Neurology \& Neuropsychiatry

TEACHING MONOGRAPH

775 Do Dual-Action Neurotransmitter Agents Offer an Advantage in Psychiatric Treatment?

By Richard C. Shelton, MD, Dennis S. Charney, MD, and Madhukar Trivedi, MD

\section{CONTINUING MEDICAL EDUCATION GradWORKS}

795 This Continuing Medical Education series gives the reader the opportunity to test his/her understanding and recall of clinical material presented in this issue. Approved for 3.0 credit hours in Category 1

\section{INDICES}

798 By subject and author

Audit Bureau of Circulations

A P P I I CA TION PENDING

Melluwerks dillia

\section{CNS Spectrums ${ }^{\circledast}$}

CNS Reviews ${ }^{\mathrm{T} M}$

TEN-The Economics of Neuroscience ${ }^{\circledast}$

Psychopharmacology Bulletin ${ }^{\mathrm{TM}}$

Primary Psychiatry ${ }^{\circ}$

Psiquiatría y Salud Integra/m

Mental Fitness

Oncology Spectrums ${ }^{\mathrm{TM}}$

For editorial and advertising inquiries, please fax 212-328-0600.

Opinions and views expressed by authors are their own and do not necessarily reflect the views of the publisher, MedWorks Media, or the editorial advisory board. Advertisements in CNS Spectrums are accepted on the basis of adherence to ethical medical standards, but acceptance does not imply endorsement by CNS Spectrums, or the publisher.

CNS Spectrums $\otimes$ is a registered trademark of CNS Spectrums, LLC, New York, NY.

CNS News ${ }^{\mathrm{TM}}$ is a trademark of MBL Communications, Inc., New York, NY.

Permission to reproduce articles in whole or part must be obtained in writing from the publisher.

Copyright $\odot 2001$ by MedWorks Media. All rights reserved. Printed in the United States. 

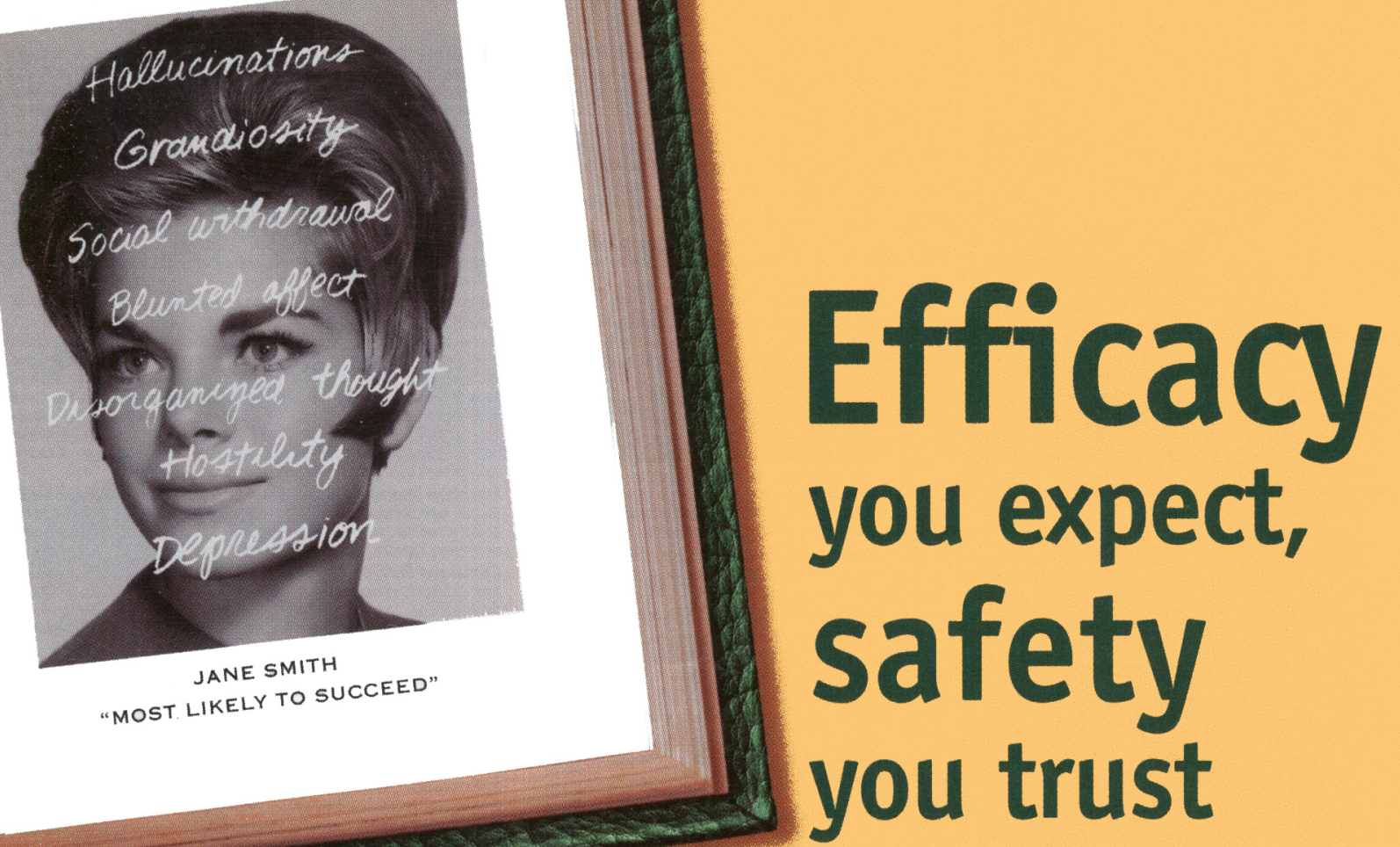

"Nothing could have

- Incidence of diabetes $<1 \%$

prepared me for the devastation of psychosis."

- Well established cardiac safety profile

- Low weight gain

- Only $5.0 \mathrm{lb}$ average in a long-term trial*

\section{"RISPERDAL gave me a new start."}
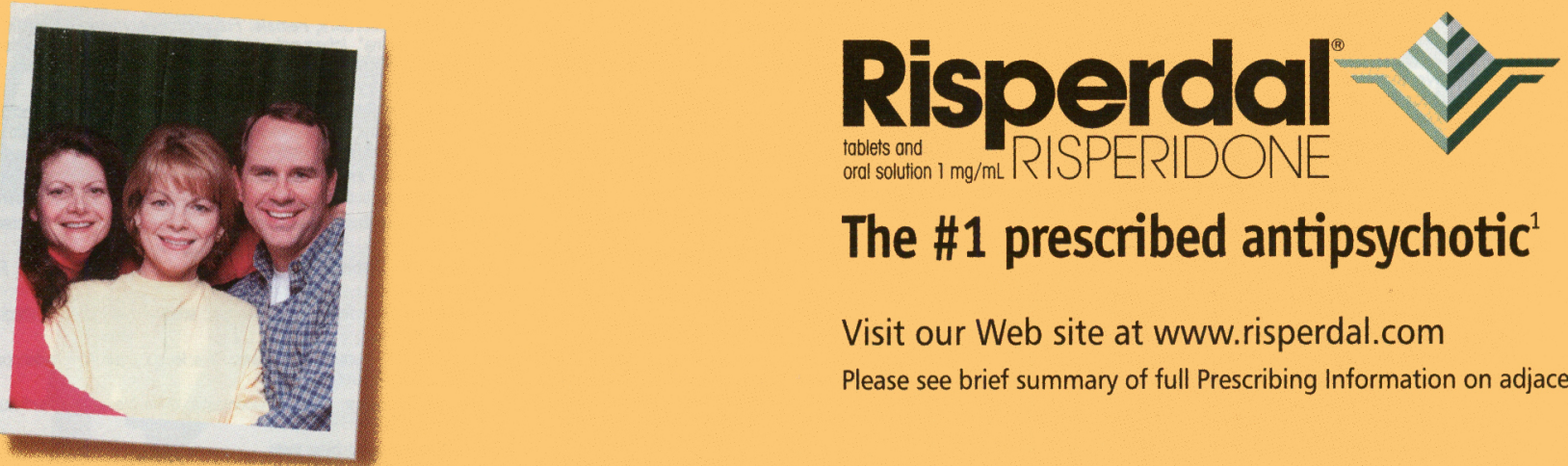

\section{The \#1 prescribed antipsychotic ${ }^{1}$}

Visit our Web site at www.risperdal.com

Please see brief summary of full Prescribing Information on adjacent page.

Reference: 1. IMS Health, NPA Plus, New and Total Prescriptions, 12 months ending November 2000

*Data on file, 2000. Submitted for publication.

In two 6- to 8-week placebo-controlled trials, spontaneously reported, treatment-emergent adverse events with an incidence of $5 \%$ or greater in at least one of the RISPERDAL groups and at least twice that of placebo were: anxiety, somnolence, extrapyramidal symptoms, dizziness, constipation, nausea, dyspepsia, rhinitis, rash, and tachycardia.

Adverse events reported since market introduction that were temporally (but not necessarily causally) related to RISPERDAL therapy include diabetes mellitus aggravated, including diabetic ketoacidosis.
Risperidone and/or 9-hydroxyrisperidone appears to lengthen the QT interval in some patients, although there is no average increase in treated patients, even at 12-16 mg/day, well above the recommended dose. Risperidone has not been evaluated in patients with a recent history of myocardial infarction or unstable heart disease.

Percentage of patients experiencing weight gain ( $\geq 7 \%$ of baseline body weight) in controlled clinical trials was $9 \%$ placebo versus $18 \%$ risperidone. This difference is statistically significant. Weight gain was dose dependent in short-term clinical trials. Other weight-related adverse events occurring in premarketing studies and listed as infrequent include increased appetite, weight increase, and weight decrease. 


\section{Risperdali}

BEFORE PRESCRIBING, PLEASE CONSULT CONPLETE PRESCRIBING INFORMATION OF WHICH THE

AISPEROAL (risperdone) is indicated tor the management of the manifestations of psychotic disorders.

CONTRAINDICATIONS

RISPERDAL (risperidone) is contraindicated in patients with a known hypersensitivity to the product.

WARNINGS

Nouroleptic Malignant Syndrome (NMS)

A potentially fatal symptom complex sometimes referred to as Neuroleptic Malignant Sy drome (NMS) has been reported in association with antipsychotic drugs. If a patient requires antipsychoic drug treatment after recovery from NMS, the potential reintroduction of drug therapy should be carefully considered. The patient shoul
NMS have been reported.

\section{Tardive Dyekinesia}

A syndrome of potentially ireversible, involuntary, dyskinetic movements may develop in patients treated with antipsychotic drugs. Whether antipsychotic drug products ditier in their potential to cause tardive dyskinesia is unknown. If signs and symptoms of tardive dyskinesia appear in a patient on RISPERDAL: drug discontinuation should be considered. However, some patients n

Potential for Proarrhythmic Eftects: Risperidone and/or 9-hydroxyrisperiPotential for Proarrhythmic Efrects: Risperidone and/or 9-hydroxyrisperi-
done appears to lengthen the QT interval in some patients, although there done appears to lengthen the QT interval in some patients, although there
is no average increase in treated patients, even at $12-16 \mathrm{mg}$ /day, well above is no average increase in treated patients, even at $12-16$ mg/day, well above
the recommended dose. Other drugs that prolong the OT interval have been associated with the occurrence of torsades de pointes, a life-threatening arnthmia. Eradycardia, electrolyte imbalance, concomitant use with other drugs that prolong QT, or the presence of congenital prolongation in QT can drugs that prolong QT, or the presence of congen
increase the risk for $\propto c c u r r e n c e$
of this arrhythmia.

PRECAUTIONS

Goporat

Orthostatic Hypotension: RISPERDAL (risperidone) may induce orthostatic hypotension associated with dizziness, tachycardia, and in some patients, syncope, especially during the initial dosetitration period, probably reflecting its alpha-adrenergic antagonistic properties. Syncope was reported in $0.2 \%$
(6/2607) of RISPERDAL treated patients in phase 2-3 studies. The risk of (6/2607) of RISPERDAL treated patients in phase 2-3 studies. The risk of Orthostatic hypotension and syncope may be minimized by limiting the initial
dose $102 \mathrm{mg}$ total (either QD or $1 \mathrm{mg}$ BDO) in normal adults and $0.5 \mathrm{mg}$ EID in the elderly and patients with renal or hepatic impairment (See DOSAGE AND ADMINISTRATION). Monitoring of orthostatic vital signs should be considered in petients for whom this is of concern. A dose reduction should be considered if hypotension occurs. AISPERDAL should be used with particular caution in patients with known cardiovascular disease (history of myocardial infiaction or schemia, heart failure, or conduction abnormalities), cerebrovascular disease,
and conditions which would predispose patients to hypotension e.g. dohydration and condtions which would predispose patients to hypotension e.g. dehydration concomitant use of RISPERDAL ${ }^{\circ}$ and antilypertensive medication.

Soizurea: RISPERDAL " should be used cautiously in petients with a history of seizures.

Dyephagin: Esophageal dysmotility and aspiration have been associated with antipsychotic drug use. Aspiration pneumonia is a common cause of mobidity and other antipsychotic drugs should be used cautiously in patients at risk for aspiration pneumonia.

Hyperprolactinomia: As with other drugs that antagonize dopamine $D$ receptors, risperidone elevates prolactin levels and the elevation persists Juring chronic administration. Neither clinical studies nor epidemiologic administration of this class of drugs and tumorigenesis in humans; the avaiadministration of this class d drugs and tumorigenesis in humans;

Potential for Cognitive and Mbtor impaiment Somnolence was a commonly reporled adverse event associated with RISPERDAL treatment, especially when ascertained by direct questioning of patients. This adverse event is dose related. Patients should be caukioned about operating hazardous machinery,
including automobiles, until they are reasonably cortain that RISPERDAL therapy does not aflect them adversely.

Priapiam: Rare cases of priapism have been reported.

Thrombotic Thrombocytopenic Purpura (TTP); A single case of TTP was reported in a 28 year-od temale patient receiving RISPERDAL in a large, coen premarketing experience (approximately 1300 patients). She experienced jaundice, fever, and bruising, but eventually recovered after recent
plasmapheresis. The retationship to RISPERDAL "therapy is unknown.

Antiomotic offect: Risperidone has an antiemetic eftect in animals; this effect may also occur in humans, and may mask signs and symptoms of over dosage with certain drugs or of conditions such as intestinal obstruction,

Body Temperature Regulation: Disruption of body temperature regulation has been attributed to antipsychotic agents. Caution is advised when preecribing for patients who will be exposed to temperature extremes.

Suicids: The possibility of a suicide attempt is inherent in schizophrenia, and close supervision of high risk patients should accompany dng therapy.

Use in Pationts with Concomitant Illness: Clinical experience with FISPERDAL- in patients with certain concomitant systemic illinesses is limited. Caution is advisable in using RISPERDAL in patients with diseases a conditions that could affect metabolism or hemodynamic responses.

Because of the risks of orthostatic hypotension and QT prolongation, caution
should be observed in cardiac patients (See WARNINGS and PRECAUTIONS). Increased plasma concentrations of risperidone and 9-hydroxyrisperidone occur in petients with severe renal impairment and in patients with sever hepetic impaiment. A lower starting dose should be used in such patients.

Information for Pationt

Physicians are advised to consult full prescribing information to review issues Drug Imaraction:

The interactions of RISPERDAL and other drugs have not been systematically evaluated. Given the primary CNS effects of risperidone, caution should be used when RISPERDAL is taken in combination with other centrally acting drugs and acchol. RISPERDAL may antagoniza the effects of levodopa and
dopamine agonists. Chronic administration of carbamazepine with risperidone dopamine agonists. Chronic administration of carbamazepine with risperidone
may increase the clearance of risperidone. Chronic administration of clozapine may increase the clearance of risperidone. Chronic administ
with risperidone may decrease the clearance of risperidone.

Fuoxetine may increase the plasma concentration of the anti-psychotic fraction (rispesidone plus 9-hydroxyrisperidone) by raising the concentration of risper
done, although not the active metabolite, g-hydroxyrisperidone.
Drugs that Inhibit Cytochrome P 110 , and Other P Isozymes: Risperidone s metabolized to 9-hydroxyrispendone by cylochrome $P_{\text {il }}$, an enzyme tha psychotropic and other drugs (Soe CLINICAL PHARMACOLOGY) Drug inteactions that reduce the metabolism of risperidone to 9-hydroxyrisperidon would increase the plasma concentrations of risperidone and lower the concentrations of 9-hydroxyrisperidone. Analysis of clinical siudies involving modest number of poor metabolizers $(n \approx 70)$ does not suggest that poor comparison of effectiveness in the two groups has been made

In vitro studies showed that drugs metabolized by other $P_{-\infty}$ isozymes, including IA1 $\uparrow A 2, \| C 9, M P$, and $\| \mathrm{AA} 4$, are only Drugs Metabolized by Cytochrome $P_{u}$ IID; In vitro studies indicate that risperidone is a relatively weak inhibito of cytochrome $P_{\text {sid }}$. The Therero, that are metabolized by this enzymatic pathway. However, clinical data to that are mitabolized by this enzymatic path

Carcinogonesis, Mutagenesis, Impairment of Fertility

Carcinogenesis: Carcinogenicity studies were conducted in Swiss albino mice and Wistar rats. Risperidone was administered in the diet at doses of $0.63,2.5$ and $10 \mathrm{mg} / \mathrm{kg}$ for 18 months $10 \mathrm{mice}$ and for 25 months to ats. These doses are equivalent to 2.4,9.4 and 37.5 times the maximum human dose ( $16 \mathrm{mg} / \mathrm{day}$ ) on a mg/kg basis of $0.2,0.75$ and 3 times the maximum human dose (mice) or were statistically significant increases in pitutary gland adenomas, endocrine pancreas adenomas and mammary gland adenocarcinomas.

These findings are considered to be prolactin medicated. The relevance for human risk of the findings of prolactin-mediated endocnine tumors in rodents

Mutagenesis: No evidence of mutagenic potential for risperidone was found. Impaiment of Fertility: Risperidone $(0.16$ to $5 \mathrm{mg} / \mathrm{kg})$ was shown to impa mating, but not fertility, in Wistar rats in thre reproductive studies at doses
0.1 to 3 times the maximum recommended human dose on a $\mathrm{mg} / \mathrm{m}^{2}$ basis. Pregnancy

Pregnancy Category C: There are no adequate and well-controlied studies pregnant women.

ISPERDAL should be used during pregnancy only if the potential benefit ustifies the potential risk to the fet us.

Labor and Delivery

of of RISPERDAL on labor and delivery in humans is unknown

Nursing Mothers

is not known whether or not risperidone is excreted in human milk. Women

Saftety and effectiveness in children have not been established

Geriatric Uee

Cinical studies of RISPERDAL did not include sufficient numbers of patients aged 65 and over to determine whather they respond differently from younger patients. Other reported clinical experience has not identified differences in responses between elderly and younger patients. In general, a lower stanting dose is recommended for an elderly patient, reflecting a decreased phamacokinetic clearance in the elderly, as well as a greater frequency of decreased hepatic enal, or cardiac function, and of concomitant disease or other drug therapy
See CLINICAL PHARMACOLOGY and DOSAGE AND ADMINIS TRATION While eiderly patients exhibit a greater tendency to orthostatic hypotension, its risk in the edderly may be minimized by limiting the initial dose to $0.5 \mathrm{mg}$ BID risk in the eldenly may be minimized by limiting the initial dose to $0.5 \mathrm{mg}$ BID
iollowed by careful titration (See PRECAUTIONS). Monitoring of orthostatic
vital signs should be considered in patients for whom this is of concern.

This drug is known to be substantially excreted by the kidney, and the risk do toxic reactions to this drug may be greater in patients with impaired rena function. Because elderly patients are more likely to have decreased renal lunction, care should be taken in dose seloction, and it may
renal function (See DOSAGE AND ADMINISTRATION).

\section{ADVERSE REACTIONS}

Associaled with Discontinuation of Treatmen

Approximately $9 \%$ percent (244/2607) of RISPERDAL (isperidone)-treator patients in phase 2-3 studies discontinued tratment due to an adverse event compared with about $7 \%$ on placebo and $10 \%$ on active control drugs. The more common events ( $\geq 0.3 \%$ ) associated with discontinuation and considered to be possibly or probably drug-related included.

Incidence in Controlled Trials

Commonly Observed Adverse Events in Controlled Clinical Trials: In two 6- to 8-week placebo-controlled trials, spontaneously-reported, treatmentemergent adverse events with an incidence of $5 \%$ or greater in at least one of somnolence, extrapyramidal symptoms, dizziness, constipation, nausea,
dyspepsia, rhinitis, rash, and tachycardia.

Adverse events were also elicited in one of these two trials (i.e., in the fixeddose trial comparing RISPERDAL at doses of 2, 6, 10, and $16 \mathrm{mg}$ /day with placebo) utilizing a checkist for detecting adverse events, a method that is
more sensitive than spontaneous reporting. By this method, the following more sensitive than spontaneous eporting. By this method, the following
additional common and drug-related adverse events were present at least $5 \%$ and twice the rate of placebo: increased dream activity, increased duration of and twice the rate of placebo: increased dream activity, increased duration of
sleep, accommodation disturbences, reduced salivation, micturition distursleep, accommodation disturbences, reduced salvation, micturition distur-
bances, diarrhea, weight gain, menorhagia, diminished sexual desire, erectile bances, diarnhea, weight gain, menormagia, diminished sexual
dystunction, ejaculatory dystunction, and orgastic dysfunction,

The following adverse everts occurred at an incidence of $1 \%$ or more, and were at least as frequent among RISPERDAL treated patients treated at doses of $\leq 10 \mathrm{mg} /$ day than among placebo-treated patients in the pooled
results of two 6- to 8-week controlled trials: Prychiatric Disorders: insomnia results of two 6- to 8-week controlled trials: Pyychiatric Disorders: insomnia,
agitation, anxiety, somnolence, aggressive reaction. Norvous System. agitation, anxiety, somnolence, aggressive reaction. Norvous System. constipation, nausea, dyspepsia, vomiting, abdominal pain, saliva increased toothache. Rospiratory System: rhinitis, coughing, sinusitis, pharyngitis,
dyspnea. Body as a Whole: back pain, chest pain, fever. Dermatological: dyspnea. Bocty as a Wholo: back pain, chest pain, fever. Dermatological:
rash, dy skin, seborrhea. Infections: upper respiratory. Visual: abnorma vision. Musculo-Skelotal: arthralgia. Cardiovascular: tachycardia. ' Includes tremor, dystonia, hypokinesia, hypertonia, hyperkinesia, oculogyric
crisis ataxia, abnormal gait, involuntary muscle contractions, hyporeflexia, akathisia, and extrapyramidal disorders.

\section{Dose Dependency of Adverse Events:}

Data from two fixed dose trials provided evidence of dose-relatedness for exrapyramidal symptorns associated with risperidone treatment. These symploms include: sleepiness, increased duration of sleep, accommodation disturtoances, orthostatic dizziness, palpitations, weight gain, erectile dysfunction,
ejaculatory dysfunction, orgastic dystunction, asthenia/lassitude/increased fatiguability, and increased pigmentation.

Vital Sign Changos: RISPERDAL is

Woight Changes: A statisticaly significantly greater incidence of weight gain or RISPERDAL $(18 \%)$ compared to placebo $(9 \%)$

Laboratory Changes: A between group comparison for 6- to 8-week placebocontrolled trials revealed no statistically significant RISPERDAL /placebo
Similarly, there were no RISPERDAL \% placebo dffierences in the incidence of discontinuations for changes in serum chemistry, hematology, of urinalysis. However, RISPERDAL administration was associated with increases in serum prolactin (Seo PRECAUTIONS)

ECG Changes: The electrocardiograms of approximately 380 patients who blind, placebo-controlled trials were evaluated and revealed one finding of potential concern; i.e., 8 patients taking RISPERDAL whose baseline QTC interval was less than $450 \mathrm{msec}$ were observed to have QTc intervals greate ware not sean among about 120 pacebo patients, but were seen in petions were not sean among about

Other Events Observed During the Pre-Marketing Evaluation of RISPERDAL.

During its premarketing assessment, multiple doses of RISPERDAL (risperidone) were administered to 2607 patients in phase 2 and 3 stucies and the following reactions were reported: (Note: frequent adverse events are those occurring in at in $1 / 100$ to $1 / 1000$ patients; rare events are those $\propto$ ccurring in fewer than $1 / 1000$ patients. It is important to emphasize that, although the events reported occurred during treatment with RISPERDAL", they were not necessarily caused by it:

Psychiatric Disorders: Frequent: increased dream activity", diminished sexue desire", nervousness. Intrequent: impaired concentration, depression, apathy nightmares, delirium, withdrawal syndrome, yawning.

Contral and Poripheral Nervous System Disorders: Frequenti increased sleep duration". Infrequent: dysarthria, vertigo, stupor, paraesthesia, confusion Rare: aphasia, cholinergic syndrome, hypoesthesia, tongue paralysis, leg cramps, torticollis, hypotonia, coma, migraine, hyperreflexia, chorecathetosis. Gastro-intestinal Disorders: Frequent: anorexia, reduced salivation" Ifrequent: flatulence, diarrhea, increased appetite, stomatitis, melena, dysphagia, hermorrhoids, gastritis. Rare: fecal incontinence, eructation, gastrocholelithiasis, tongue edema, diverticulitis, gingivitis, discolored feces, G .

Body as a WholdGoneral Disorders: Frequent: fatigue. Intrequant: edema, rigors, malaise, influenza-like symptoms. Aare: pallor, enlarged abdomer, alergic reaction, ascites, sarcoidosis, flushing.

Rospiratory Systom Disorders: Intrequent typerventilation, bronchospasm, neumonia, stridor. Rare: asthma, increased sputum, aspiration.

Skin and Appendage Dieorders: Frequent increased pigmentation", photosensitivity". Infrequent: increased sweating, acne, decreased sweating ulceration, aggravated psoriasis, furunculosis, verruca, dermatitis lichenoid, hypertichosis, genital pruritus, urticaria.

Cardiovascular Disordors: intrequent: palipitation, typertension, hypotension, AV block, myocardial infarction. Rare: ventricular tachycardia, angina pectoris depression, myocard'tis.

Vision Disorders: Infrequent: abnormal accommodation, xerophthalmia Rare: diplopia, eye pain, blepharitis, photopsia, photophobia, abnorma

Motabolic and Nutritional Disorders: infrequent: hyponatremia, weight

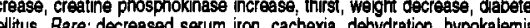
ypoproteinemia, hyperphosphatemia, hypertriglycericemia, hyperuricemia, hypoglycemia.

Urinary System Disorders: Frequent: polyuria/polydipsia". Infrequen insufficiency.

Musculo-skelatal System Disordors: Infrequent: myalgia. Rare: anthrosis ynostosis, bursitis, arthritis, skeletal pain.

Reproductive Disordors, Fomale: Frequent: menorrhagia", orgastic dysfunction", dy vagina". Intrequent: nonpuerperal lactation, amenoritea, female breast pain, leukornhea, mastitis, dysmencrit

Liver and Biliany Syotem Disordors: Infrequent: increased SGOT, increased SGPT Rare: hepatic failure, cholest

Platelot, Blooding and Clotting Disondors: Intrequent: epistaxis purpure, Rare: hemorrhage, superficial phlebitis, thrombophlebitis, thrombocytopenia. Hearing and Vestbular Disonders: Rare: tinnitus, hyperacusis, decreased

Aod Blood Cell Disorders: Intrequent: anemia, hypochlomic anemia. Fare normocytic anemia.

reproductive Disor

White Coll and Resistance Disorders: Aare: leukocylosis, lymphadenopathy, Ucopenia, Pelger-Huet anomaly.

Endocrine Disorders: Rare: gynecomastia, male breast pain, antidiuretic ormone disorder.

Special Senees: Rare: bitter taste.

Pidence based on elicited reparts.

Postintroduction Reports: Adverse events reported since market introduction which were temporally (but not necessarily causally) related to edema, apnea, atrial tibrillation, cerebrovascular disorder, diabeles mellitus edema, apnea, atrial ibrilation, cerebrovascular disorder, diabotes meltus
aggravated, including diabetic ketoacidosis, intestingl obstruction, jaundice, maniavated, including diabetic ketoacidosis, intestinal obstruction, jaundice,
manceatitis, Parkinson's disease aggravated, pulmonary embolism. There have been rare repotts of sudden deeth andor carciopulmonary arrest in patients receiving RISPERDAL. A causal relationship with FISPERDAL in patients receiving RISPERDAL. A causal relationship with RISPERDAL death may occur in psychotic patients whether they remain untreated or death may occur in psychotic patients whether they

DRUG ABUSE AND DEPENDENCE

Controllod Substance Clsas: RISPERDAL (risperidone) is not a controlled substance.

For information on symptoms and treatment of overdosage,

Wore detailed professional intormation is available upon request.

O Janssen Pharmacentica inc. 1999

US Patent 4,804,663
July 1998, May 1999

7503217

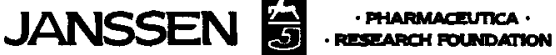

Titusville, NJ 08560 


\section{$F I V E_{\text {reasons to }}$ consider the proven efficacy $y^{1.2}$ of ADDERALL" for the ADHD patients in your practice...}
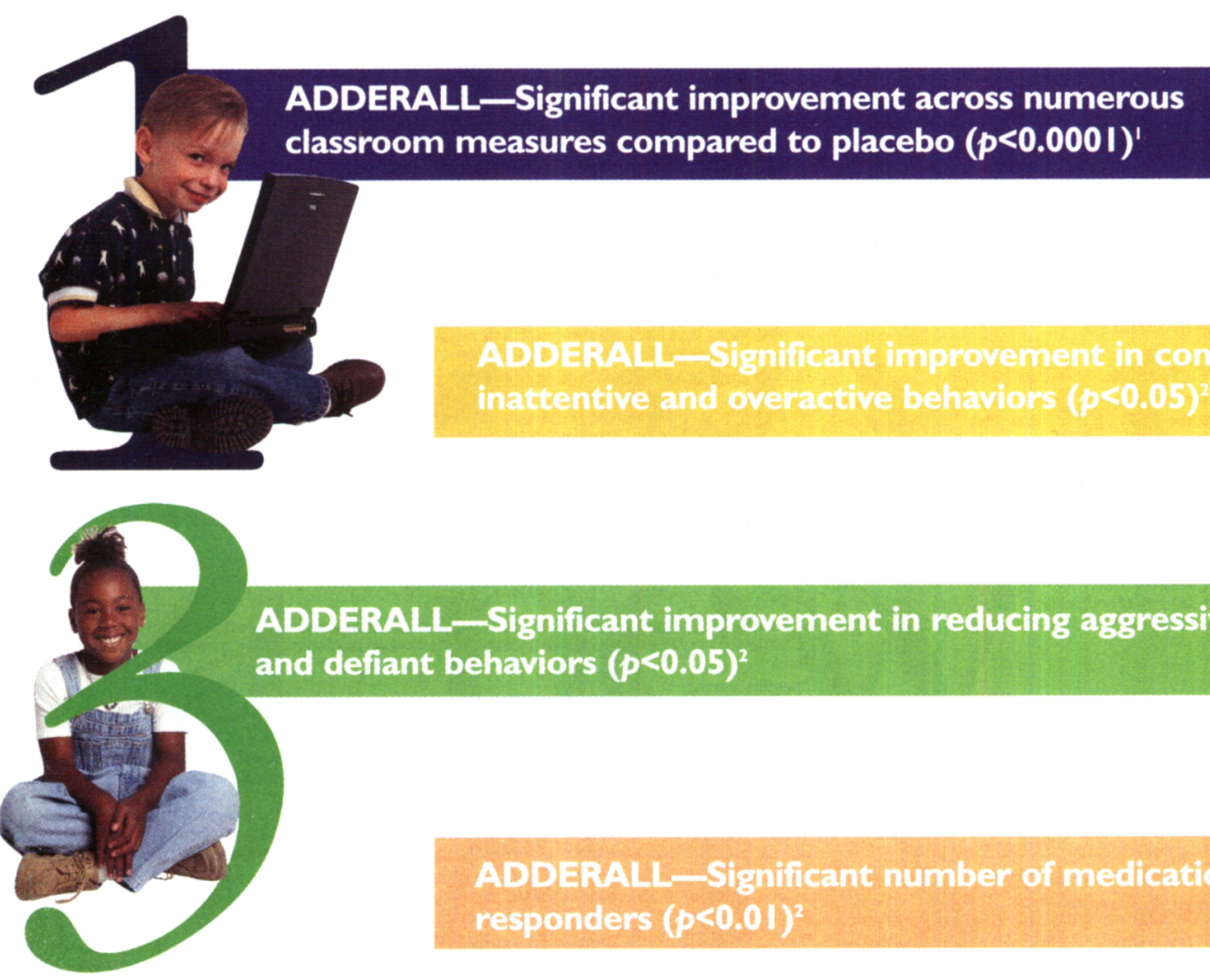

ADDERALL_-Significant improvement in reducing aggressive and defiant behaviors $(p<0.05)^{2}$

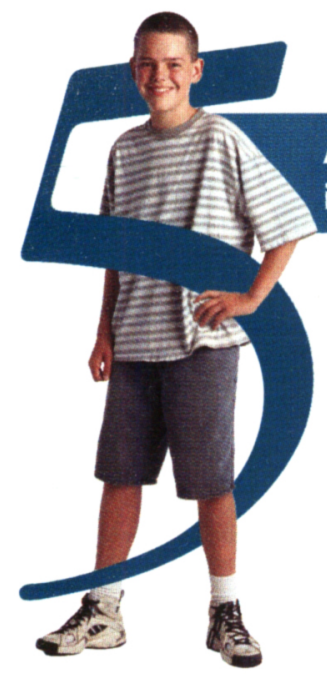

ADDERALL_Significant Clinical Global Impression (CGI) improvement scores $(p<0.05)^{2}$

ADDERALL is generally well tolerated. The most frequently reported adverse reactions inchude anorexia, insomnia, stomach pain, beadache, irritability, and weight loss. As with other psychostimulants indicated for ADHD, there is a potential for precipitating motor tics and Tourette's syndrome. In rare cases, psychosis has been reported. ADDERALL is contraindicated in patients with symptomatic cardiovascular disease, moderate to severe bypertension, or bistory of drug abuse. Amphetamines may exacerbate symptoms of behavior disturbance and thought disorder in psychotic children. The possibility of growth inbibition warrants monitoring growth during treatment. ADDERALL should be prescribed only as part of an overall multimodal treatment program for $A D H D$ with close physician supervision.

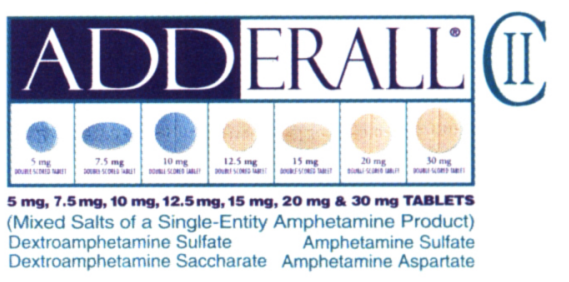


References: 1. Pelham WE, Aronoff HR, Midlam JK, et al.A comparison of Ritalin and Adderall: efficacy and time-course in children with attentiondeficit/hyperactivity disorder. Pediatrics [serial online]. 1999;103:e43. Available at: http://www.pediatrics.org/. 2. Pliszka S, Browne RG,Wynne SK, et al. Comparing Adderall and methylphenidate in ADHD. J Am Acad Child Adolesc Psychiatry. 2000; 39(5):619-626.

\section{AI)DERALLII

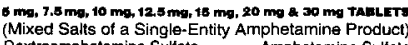

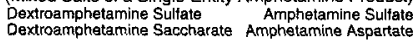

AMPHETAMINES HAVE A HIGH POTENTIAL FOR ABUSE. ADMINISTRATION OF AMPHETAMINES FOR PROLONGED PERIODS OF TIME MAY LEAD TO DRUG DEPENDENCE AND MUST BE AVODED. PARTICULAR ATTENTION
SHOULD BE PAIDTO THE POSSIBLILTY OF SUBJECTS OBTAINING AMPHETAMINES FOR NON.THERAPEUTIC USE SHOULD BE PAD TO THE POSSIBILITY OF SUBJECTS OBTAINING AMPHETAMINES FOR NON-THERAPEUUTC
OR DISTRIBUTION TO OTHERS, AND THE DRUGS SHOULD BE PAESCRIBED OR DISPENSED SPARINGLY.

DESCAIPTION: A single entity amphetamine product combining the neutral sulfate salts of dextroamphetamine and amphetamine, with the dextro isomer of amphetamine saccharate and d l-amphetamine aspartate.

$\begin{array}{lcllllll}\text { EACH TABLET CONTAINS: } & 5 \mathrm{mg} & 7.5 \mathrm{mg} & 10 \mathrm{mg} & 12.5 \mathrm{mg} & 15 \mathrm{mg} & 20 \mathrm{mg} & 30 \mathrm{mg} \\ \text { Dextroamphetamine Saccharate } & 1.25 \mathrm{mg} & 1.875 \mathrm{mg} & 2.5 \mathrm{mg} & 3.125 \mathrm{mg} & 3.75 \mathrm{mg} & 5 \mathrm{mg} & 7.5 \mathrm{mg} \\ \text { Amphetamine Aspartale } & 1.25 \mathrm{mg} & 1.875 \mathrm{mg} & 2.5 \mathrm{mg} & 3.125 \mathrm{mg} & 3.75 \mathrm{mg} & 5 \mathrm{mg} & 7.5 \mathrm{mg} \\ \text { Dextroamphetamine Sulfate USP } & 1.25 \mathrm{mg} & 1.875 \mathrm{mg} & 2.5 \mathrm{mg} & 3.125 \mathrm{mg} & 3.75 \mathrm{mg} & 5 \mathrm{mg} & 7.5 \mathrm{mg} \\ \text { Amphetamine Sulfale USP } & 1.25 \mathrm{mg} & 1.875 \mathrm{mg} & 2.5 \mathrm{mg} & 3.125 \mathrm{mg} & 3.75 \mathrm{mg} & 5 \mathrm{mg} & 7.5 \mathrm{mg} \\ \text { Total amphetamina base equivalence } & 3.13 \mathrm{mg} & 4.7 \mathrm{mg} & 6.3 \mathrm{mg} & 7.8 \mathrm{mg} & 9.4 \mathrm{mg} & 12.6 \mathrm{mg} & 18.8 \mathrm{mg}\end{array}$

Inactive Ingredients: sucrose, lactose, corn starch, acacia and magnesium stearate.

Colors: ADDERALL $5 \mathrm{mg}, 7.5 \mathrm{mg}$ and $10 \mathrm{mg}$ contain FD \& C Blue \#1.

ADOERALL $12.5 \mathrm{mg}, 15 \mathrm{mg}, 20 \mathrm{mg}$ and $30 \mathrm{mg}$ contain FO \& C Yellow $\# 6$ as a color additive.

CLINICAL PHARMACOLOGY: Amphetamines are non-catecholamine sympathomimetic amines with CNS stimulan activity. Peripheral actions include elevation of systolic and diastolic blood pressures and weak bronchodilator and respiratory stimulant action

There is neither specific evidence which clearly establishes the mechanism whereby amphetamine produces ment and behavioral effects in children, nor conclusive evidence regarding how these effects relate to the condition of the central iny

INDICATIONS: Altention Deficit Disonder with Hyperactivity: Adderall is indicated as an integral part of a total treatment program which typically includes other remedial measures (psychological, educational, social) tor a stabilizing effect in children with behavioral syndrome characterized by the tollowing group of developmentally inappropriate symptom moderate to severe distractibility, short attention span, hyperactivity, emotional lability, and impulisivity. The diagnosis of this syndrome should not be made with finality when these symptoms are only of comparatively recent origin. Nonlocalizing (soft) neurological signs, learning disability and abnormal $E \mathrm{EG}$ may or may not be present, and a diagnosis of central nerous system dystunction may or may not be warranted.

In Narcolepsy

CONTRAINDICATIONS:

Advanced arteriosclerosis, symptomatic cardiovascular disease, moderate to severe hypertension, hyperthyroidism, know hypersensitivity or idiosyncrasy to the sympathomimetic amines, glaucoma.

Agitated states.

Patients with a history of drug abuse.

During or within 14 days following the administration of monoamine oxidase inhibitors (hypertensive crises may result)

WARNINGS: Clinical experience suggests that in psychotic children, administration of amphetamine may exacerbate symptoms of behavior disturbance and thought disorder. Data are inadequate to determine whether chronic administration

Usace in Nursing Mothers: Amphotamines are excreted in human milk. Mothers taking amphetamines should be advised Usage in Nursing Moth

PRECAUTIONS: General; Caution is to be exercised in prescribing amphetamines for patients with even mild hypertension.

The least amount teasible should be prescribed or dispensed at one time in order to minimize the possibilly of overdosage Information for Patients: Amphetamines may impair the ability of the patient to engage in potentially hazardous activitiss such as operating machinery or vehicles; the patient should therefore be cautioned accordingly.

Drug Interactions: Acidifying agents - Gastrointestinal acidifying agents (guanethidine, reserpine, glutamic acid HO ascorbic acid, fruit juices, etc.) lower absorption of amphetamines.

Urinary acidithing agents

(ammonium chloride, sodium acid phosphate, etc.) Increase the concentration of the ionized species of the amphetamine molesule, thereby increasing urinary excretion. Both groups of agenis lower blood ievels and efficacy of amphetamines. Adrenergic blockers -

Adrenergic blockers are inhibited by amphetamines

Alkalinizing agents

Gastriointestinal alkailizing agents (sodium bicarbonate, etc.) increase absorption of amphetamines. Urinary alkalinizing agents (acetazolamide, some thiazides) increase the concentration of the non-ionized species of the amphetamine mol: cule, thereby decreasing urinary excretion. Both groups of agents increase blood levels and therefore potentiate the actions of amphetamines.

Antidepressants, tricyclic -

Amphetamines may enhance the activity of tricyclic or sympathomimetic agents; d-amphetamine with desipramine or protriptyine and possibly other tricyclics cause striking and sustained increases in the concentration of d-amphetamine in the brain; cardiovascular effects can be potentiated.

MAO inhibitors

MAOI antidepressants, as well as a metabolite of furazolidone, slow amphetamine metabolism. This slowing potentiates amphetamines, increasing their effect on the release of norepinephrine and other monoamines from adrenergic nerve endings; this can cause headaches and other signs of hypertensive crisis. A variety of neurological toxic effects and malignan hyperpyrexia can occur, sometimes with hatal results.

Anthistamines.

Amphetamines may counteract the sedative effect of antihistamines.

Antihypertensives.

Amphetamines may antagonize the hypotensive effects of antihypertensives.

Chlorpromazine -
Chlorpsomazine biocks dopamine and norepinephrine receptors, thus inhibiting the central stimulant effects of amphetaminss, and can be used to treat amphetamine poisoning.

Ethosuximide -

Amphetamines may delay intestinal absorption of ethosuximide.

Haloperidol-

Haloperidol blocks dopamine receptors, thus inhibiting the central stimulant effects of amphetamines.

Lithium carbonate.

The anorectic and stimulatory effects of amphetamines may be inhibited by lithium carbonate.

Meperidine -

Amphetamines potentiate the analgesic effect of meperidine.

Methenamine therapy

Urinary excretion of amphetamines is increased, and efficacy is reduced, by acidifying agents used in methenamin

therapy.

Norepinephrine -

Amphetamines enhance the adrenergic effect of norepinephrine.

Phenobarbital -

Amphetamines may delay intestinal absorption of phenobarbitial; co-administration of phenobarbital may produce a syne gistic anticonvulsant action

Phempoin:

Amphetamines may delay intestinal absorption of phenytoin; co-administration of phenytoin may produce a synergistic ant corvulsant action.

In cases of propoxyphene overdosage, amphetamine CNS stimulation is potentiated and fatal convulsions can occur. Veratrum alkaioids.

Amphetamines inhibit the hypotensive effect of veratrum alkaloids.
Druglaboratory Test Interactions

- Amphetamines can cause a significant elevation in plasma corticosteroid levels. This increase is greatest in the evening - Amphotan interere with urinary steroid determinations

Carcinogenesis MMutagenesis: Mutagenicity studies and long-term studies in animals to determine the carcinogenic potential of amphetamine, have not been performed.

Pregnancy - Teratogenic Effects: Pregnancy Category C. Amphetamine has been shown to have embryotoxic and teratogenic effects when administered to A/Jax mice and C57BL mice in doses approximately 41 times the maximum human dose. Embryotoxic effects were not seen in New Zealand white rabbits given the drug in doses 7 times the human dose nor in rals given 12.5 times the maximum human dose. While there are no adequate and well-controlled studies in pregnant women, there has been one report of severe congenital bony deformity, fracheoesophageal fistula, and anal atresia (vater association) in a baby born to a woman who took dextroamphetamine sultate with lovastatin during the first trimester of pregnancy

tifies the potential risk to the fetus. delivery and low birth weight. Also, these intants may experience symptoms of withdrawal as demonstrated by dysphoria, including agitation, and signiticant lassitude.

Pediatric Use: Long-term eflects of amphetamines in children have not been well established. Amphetamines are no Pediatric Use: Long-term eflects of amphetamines in children have not been well established. Amphetamines are no
recommended for use in children under 3 years of age with Attention Deficit Disorder with Hyperactivity described recommended for use in children $U$,
under INDICATIONS AND USAGE.

Amphetamines have been reported to exacerbate motor and phonic tics and Tourette's syndrome. Therefore clinical evaluation for tics and Tourette's syndrome in children and their tamilies should precede use of stimulant medications Drug treatment is not indicated in all cases of Atlention Deficit Disorder with Hyperactivity and should be considered only in light of the complete history and evaluation of the child. The decision to prescribe amphetamines should depend on the physician's assessment of the chronicity and severity of the child's symptoms and their appropriateness
for hishther age. Prescription should not depend solely on the presence of one or more of the behavioral characteristics. When these symptoms are associated with acute stress reactions, treatment with amphetamines is usually not indicated.

Cardiovascular: Palpitations, tachycardia, elevation of blood pressure. There have been isolated reports of cardiomyopathy associated with chronic amphetamine use

Central Nervous System: Psychotic episodes at recommended doses (rare), overstimulation, restlessness, dizziness, insomnia, euphoria, dyskinesia, dysphoria, tremor, headache, exacerbation of motor and phonic tics and Tourette's syndrome.

Gastrointestinal: Dryness of the mouth, unpleasant taste, diarrhea, constipation, other gastrointestinal disturbances. Anorexia and weight loss may occur as undesirable effects when amphetamines are used for other than the anorectic efiect.

Allergic: Urticaria

Endocrine: Impotence, changes in libido.

DRUG ABUSE AND DEPENDENCE: Dextroamphetamine sulfate is a Schedule II controlled substance.

Amphetamines have been extensively abused. Tolerance, extreme psychological dependence, and severe socia disally have occurred There are reports of patients who have increased the dosage to many times that recommend. - Abrupt cessation following prolonged high dosage administration results in extreme fatigue and mental depression changes are also noled on the sleep EE. Manlessations of chronic intoxication with amphetanines include severe derintoxication is peychosis a, OVERDOSAGE: Individual patient response to amphetamines varies widely. While toxic symptoms occasionally occur as an idiosyncrasy at doses as low as $2 \mathrm{mg}$, they are rare with doses of less than $15 \mathrm{mg} ; 30 \mathrm{mg}$ can produce severe reactions, yet doses of $40010500 \mathrm{mg}$ are not necessarily fatal.

in rats, the oral $L D_{50}$ of dextroamphetamine sulfate is $96.8 \mathrm{mg} / \mathrm{kg}$.

Symptoms: Manifestations of acute overdosage with amphetamines include restlessness, tremor, hyperreflexia, rapid respiration, confusion, assaultiveness, hallucinations, panic states, hyperpyrexia and rhabdomyolysis.

Fatigue and depression usually follow the central stimulation.

Carciovascular effects include arrhythmias, hypertension or hypotension and circulatory collapse.

Gastrointestinal symptoms include nausea, vomiting, diarnea, and abdorninal cramps. Fatal poisoning is usually preceded by convulsions and coma.

Treatment: Consult with a Certified Poison Control Center for up to date guidance and advice. Management of acute amphetamine intoxication is largely symptomatic and includes gastric lavage, administration of activated charcoal administration of a cathartic and sedation. Experience with hemodialysis or peritoneal dialysis is inadequate to permi recommendation in this regard. Acidification of the urine increases amphetamine excretion, but is believed to increase
risk of acute renal failure if myoglobinuria is present. If acute, severe hypertension complicates amphetamine overdosage, administration of intravenous phentolamine has been suggested. However, a gradual drop in blood pressure will usually result when sutficient sedation has been achieved. Chlorpromazine antagonizes the central stimulant effects of amphetamines and can be used to treat amphetamine intoxication.

DOSAGE AND ADMINISTRATION: Regardless of indication, amphetamines should be administered at the lowest effective dosage and dosage should be individually adjusted. Late evening doses should be avoided because of the resulting insomnia

Attention Deficit Disorder with Hyperactivity: Not recommended for children under 3 years of age. In children from 3 to 5 years of age, start with $2.5 \mathrm{mg}$ daily; daily dosage may be raised in increments of $2.5 \mathrm{mg}$ at weekly intervals unti is obtained.

In children 6 years of age and older, start with $5 \mathrm{mg}$ once or twice daily; daily dosage may be raised in increments of $5 \mathrm{mg}$ at weekly intervals until optimal response is obtained. Only in rare cases will it be necessary to exceed a total 0 $40 \mathrm{mg}$ per day. Give first dose on awakening; additional doses (1 or 2) at intervals of 4 to 6 hours.

Where possible, drug administration should be interrupted occasionally to determine if there is a recurrence of behavioral symptoms sufficient to require continued therapy.

Narcolepsy: Usual dose $5 \mathrm{mg}$ to $60 \mathrm{mg}$ per day in divided doses, depending on the individual patient response.

Narcolepsy seldom occurs in children under 12 years of age; however, when it does, dextroamphetamine sulfate may be used. The suggested initial dose for patients aged 6.12 is $5 \mathrm{mg}$ daily; daily dose may be raised in increments of 5 $\mathrm{mg}$ at weekly intervals until optimal response is ottained. In patients 12 years of age and older, start with $10 \mathrm{mg}$ daily mg at weekiy intervals until optimal response is obtained. In patients 12 years of age and oider, start with 10 mg daily; some adverse reactions appear (e.g., insomnia or anorexia), dosage should be reduced. Give first dose on awakening additional doses (1 or 2 ) at intervals of 4 to 6 hours.

HOW SUPPLIED:

ADDERALL" $5 \mathrm{mg}$. Blue double-scored tablet, debossed "AD" on one side and " 5 " on the other side (NDC 58521.031-01)

ADDERALL" $7.5 \mathrm{mg}$ : Blue double-scored tablet, debossed "AD" on one side and "7.5" on the other side (NDC 58521.075-01) ADDERALL ADDERALL 12.5 mg. Orange double scored tablet, debossed "AD" on one side and " 12.5 " on the other side (NDC 58521-125-1) ADDERALL $15 \mathrm{mg}$ : Orange double-scored tablet, debossed "AD" on one side and "15" on the other side (NDC 58521-150-01)
ADDERALIL $20 \mathrm{mg}$ : Orange double-scored tablet, debossed "AD" on one side and "20" on the other side (NDC 58521-033-01) ADDERALL $20 \mathrm{mg}$ : Orange double-scored tablet, debossed "AD" on one side and "20" on the other side (NDC 58521-033-01)
ADDERALL" $30 \mathrm{mg}$ : Orange double-scored tablet, debossed "AD" on one side and "30" on the other side (NDC 58521-034-01) in bottles of 100 tablets.

Dispense in a tight, light-resistant container as detined in the USP,

Store at controlled room temperature $15^{\circ}-30^{\circ} \mathrm{C}\left(59^{\circ}-86^{\circ} \mathrm{F}\right)$

Rx only.

MG \#10185

Revised: APRIL 2000

Shire Richwood Inc.

Florence, KY 41042
$1-800-536-7878$ 
